\title{
Foliage and fruit susceptibility of a pecan provenance collection to scab, caused by Venturia effusa
}

Clive H. Bock ${ }^{1 *}$, Yanina Alarcon², Patrick J. Conner ${ }^{3}$, Carolyn A. Young ${ }^{2}$, Jennifer J. Randall ${ }^{4}$, Cristina Pisani $^{1}$, Larry J. Grauke ${ }^{5}$, Xinwang Wang ${ }^{5}$ and Maria J. Monteros ${ }^{2}$

\begin{abstract}
Background: Pecan (Carya illinoinensis) is an important native nut crop in the southern USA. In the Southeast, scab (caused by Venturia effusa) is a major constraint to production, and can result in significant yield losses. The breadth of sources of resistance are poorly defined, and the genetics of resistance has not been established. The aim of this study was to assess the severity of pecan scab on foliage and fruit of the trees in a collection at Georgia, USA, of 875 native pecan genotypes from 93 families in 19 provenances in various states in the USA and Mexico.

Methods: The scab responses on foliage and fruit on each pecan tree was visually assessed in 2018 and 2019. Both a most severe measure (most severely infected leaf or fruit), and an overall tree rating was taken. Scab severity data were analyzed using a mixed linear model with means separation to explore provenance and family within provenance scab susceptibilities.
\end{abstract}

Results: Significant differences in scab susceptibility between provenances and among families within provenances were detected. Trees from provenances in Illinois, Kansas, Kentucky, Missouri, Mississippi, Tennessee and Texas, USA, showed the greatest resistance (based on mean scab severity) for both foliar and fruit scab. Assessments of scab on foliage and fruit gave similar results, as did the values for the most severe scab in the tree and the overall scab severity score. Of the 875 trees assessed, 201 trees had no detectable scab symptoms on foliage or fruit in either year. An additional 116 trees were free of scab symptoms on foliage but did not produce fruit in either year. Those provenances, families within provenances and trees with greatest resistance to scab most often originated from provenance locations with higher rainfall and consequently would be under selection to adapt to scab.

Conclusions: Identifying populations with most diverse resistance, and those most consistently resistant trees can serve as a resource to develop a better understanding of the scab resistance mechanisms. These natural sources of scab resistance coupled with molecular and genomics tools will contribute to the accelerated development of new pecan cultivars with durable resistance to scab.

Keywords: Disease severity, Disease assessment, Disease control, Host resistance, Plant breeding

\footnotetext{
*Correspondence: clive.bock@usda.gov

1 United States Department of Agriculture (USDA)-Agriculture Research Service (ARS), Southeastern Fruit and Tree Nut Research Lab, 21 Dunbar Road, Byron, GA 31008, USA

Full list of author information is available at the end of the article
}

\section{Background}

Pecan (Carya illinoinensis (Wangenh.) K. Koch) is an important native nut crop in the southern Unites States (USA) and is commercially cultivated from Georgia (GA) in the east to California (CA) in the west, and as far north as Illinois (IL) (Wood et al. 1990; Blayney and Gutierrez 2017; Wells 2017; USDA 2020). Georgia frequently adaptation, distribution and reproduction in any medium or format, as long as you give appropriate credit to the original author(s) and the source, provide a link to the Creative Commons licence, and indicate if changes were made. The images or other third party material in this article are included in the article's Creative Commons licence, unless indicated otherwise in a credit line to the material. If material is not included in the article's Creative Commons licence and your intended use is not permitted by statutory regulation or exceeds the permitted use, you will need to obtain permission directly from the copyright holder. To view a copy of this licence, visit http://creativeco mmons.org/licenses/by/4.0/. The Creative Commons Public Domain Dedication waiver (http://creativecommons.org/publicdomain/ zero/1.0/) applies to the data made available in this article, unless otherwise stated in a credit line to the data. 
produces more pecans than any other state, but other states contribute to the overall production in the USA (Blayney and Gutierrez 2017; USDA 2020). Many abiotic and biotic constraints affect pecan production across this geographical range (Goff et al. 1996; Conner and Worley 2000; Wood et al. 2003; Thompson and Conner 2012). In the Southeast region, scab (caused by the plant pathogenic fungus Venturia effusa (G. Winter) Rossman \& W.C. Allen) is the single most important disease-related constraint (Thompson and Conner 2012). Scab-susceptible pecan cultivars are grown in states in the southeastern region, including Alabama (AL), Arkansas (AR), Florida (FL), GA, IL, Louisiana (LA), Mississippi (MS), Missouri (MO), Oklahoma (OK), Tennessee (TN), and Texas (TX). The risk from the disease in these regions and the impact of scab on yield is well-characterized (Hunter 1983; Gottwald and Bertrand 1988; Sanderlin 1995; Stevenson and Bertrand 2001; Bock et al. 2017a). Severe fruit infection can result in major yield loss, or complete crop loss. Although some resistant pecan genotypes exist (Sparks 1992; Thompson and Conner 2012), much of the existing and expanding pecan acreage includes scab-susceptible cultivars (Wells 2014).

The scab pathogen infects the leaves, fruit and twigs. Symptoms are characterized initially by small, roughly circular lesions that expand to a few $\mathrm{mm}$ in diameter and are typically olive-brown in color, velvety in appearance and with an irregular outline (Demaree 1928). As they age, the lesions lose their velvety appearance and become silvery and necrotic. Lesions on leaves, fruit and shoots are similar, but those on shoots and fruit shucks generally develop a clearly visible stroma. The stroma in lesions on the shoots appear to be the source of asexually produced primary inoculum each season (Demaree 1924). Venturia effusa reproduces in the field through conidia, which are rain and wind dispersed (Gottwald and Bertrand 1982; Sparks et al. 2009). Infections caused by conidia have a short latent period and can produce spores within 7 to 10 days post infection. Whereas leaves remain susceptible only during expansion (Gottwald 1985), the fruit are susceptible throughout their development and maturation (Gottwald and Bertrand 1983). The sexual stage has been described in vitro (Charlton et al. 2020), but is pending observation in the field. The genetic diversity and structure of the pathogen population is typical of a sexually reproducing pathogen (Bock et al. 2017b). Furthermore, the mating types of the fungus are in equilibrium in the field (Young et al. 2018), indicating a sexual stage does occur. Pathogenic diversity is demonstrated with isolates generally affecting one or at most a few pecan cultivars or genotypes (Converse 1960; Conner and Stevenson 2004; Conner 2013). Durability of resistance has been an issue, and several initially resistant cultivars have become increasingly susceptible, eventually resulting in failure of control (Cole and Gossard 1956; Goff et al. 1996; Thompson and Conner 2012). A few cultivars including 'Elliott' have shown durable resistance over the years.

Current strategies to control scab in the field largely rely on the use of fungicides. However, uniform application is challenging in many orchards due to large tree sizes (pecan trees can be as tall as $44 \mathrm{~m}$ (Stone 1993), although in orchards usually they do not exceed $\sim 25 \mathrm{~m}$ ) in established plantings (Bock et al. 2017a). Growers apply ten or more fungicide applications per growing season to control scab in the southeastern USA (Brenneman et al. 1999). However, fungicide resistance is an issue with $V$. effusa, and the fungus shows resistance to several classes of fungicides (Standish et al. 2020), threatening the viability of fungicides to manage the disease. Natural host resistance exists with several cultivars selected by growers or developed by the University of Georgia and the USDA-ARS that are currently resistant to scab (Thompson et al. 2008; Thompson and Conner 2012; Conner 2018). However, susceptible cultivars still predominate in the field and the genetic basis of scab resistance is poorly understood (Thompson and Conner 2012). The pathogen may adapt to novel sources of resistance in new cultivars, and once this happens, fungicides need to be applied for the life of the orchard (which could be 80 years or more). It takes approximately 25 years to develop a scab resistant cultivar, and sources of resistance tapped thus far are limited (Thompson and Grauke 1994). Furthermore, other agronomic criteria are critical in addition to scab resistance: large nut size, early harvest date and, high kernel quality, and combining these in grower or consumer acceptable genotypes can be time consuming. Therefore, finding novel sources of resistance to scab remains a priority, as does understanding the genetic basis for resistance, identifying the genes involved, and eventually harnessing this knowledge to develop cultivars with multiple mechanisms to achieve a more durable resistance. Only limited knowledge exists on the genetics of scab resistance in pecan (Thompson and Grauke 1994; Thompson and Conner 2012).

Some molecular markers were developed for pecan (Conner and Wood 2001; Grauke et al. 2003; Beedanagari et al. 2005; Chaney et al. 2015), a pecan genome was recently published (Huang et al. 2019), and others are in progress (Jenkins et al. 2015). These resources will facilitate the development of scab resistant cultivars in the future. Using these novel tools will contribute to development of more scab resistance-specific markers that will aid development of resistance in pecan to scab. Understanding the range of resistance available and locating novel sources of resistance within the species for deployment in a breeding program are priorities to maintain 
and increase production of commercially grown pecans. A provenance collection of pecan representing the native range of the species was planted in Georgia (Grauke et al. 1989, 2011; Wood et al. 1998; Rüter et al. 1999). The collection was characterized for scab resistance based on various measures of foliar scab ratings during 3 years (1998, 2013 and 2014) (Bock et al. 2016a). Only portions of the collection were assessed in 2013 and 2014. Further, ratings for fruit scab severity are not available for any of the trees in the collection. It is unclear if fruit ratings are always correlated with leaf scab severity ratings. Efforts to generate scab ratings for the entire collection can maximize its utility as a resource for both the study of resistance and for developing new resistant cultivars for the pecan industry in the USA. Establishing the susceptibility of the entire collection of pecan trees based on both foliar and fruit ratings can facilitate comparisons between trees and their relative ranking using ratings collected during the same time period. Due to the differences in the duration that foliage and fruit are susceptible to scab, as noted above (Gottwald and Bertrand 1983; Gottwald 1985), assessment of fruit may provide a more definitive and sensitive measure of susceptibility. During the period from fruit set to maturation, the fruit are susceptible and subject to incremental infection based on the environmental conditions including rainfall patterns, in addition to the presence of inoculum (Gottwald and Bertrand 1982; Sparks et al. 2009).

The objectives of this study were to (1) assess the severity of pecan scab on foliage of all 875 trees in the provenance collection over 2018 and 2019, (2) assess fruit scab on all trees producing fruit, (3) determine the relative susceptibility of provenances and families within provenances based on a "most severe scab" rating and an "overall scab severity" rating for comparison, (4) determine any associations with geographical variables and leaf traits, and (5) assess the heritability of scab-related traits.

\section{Materials and methods Provenance collection}

The pecan provenance collection is located at the USDAARS Southeastern Fruit and Tree Nut Research Laboratory in Byron, GA ( $\left.32^{\circ} 39^{\prime} 54^{\prime \prime} \mathrm{N}, 83^{\circ} 44^{\prime} 31^{\prime \prime} \mathrm{W}\right)$. The location is $156 \mathrm{~m}$ above sea level, and has 240 freezefree days (days when the temperature is $\leq 0{ }^{\circ} \mathrm{C}$ ) per year, with an annual mean precipitation of $118 \mathrm{~cm}$. The soils are characterized as Faceville sandy loams [FoA; fine, Kaolintic, thermic Typic Kandiudult soil]. The 875 trees represent collections of pecans from 19 provenances across the native range from locations in Missouri in the northern US to Oaxaca in southern Mexico (Fig. 1). Nuts from five to six arbitrarily selected trees were sampled in each provenance during 1986 and 1987 (Wood et al. 1998). Distance between sampled trees was $50 \mathrm{~m}$ to $10 \mathrm{~km}$ at each provenance to reflect the genetic nature in that area. Nuts from each tree represented a 'family' and are considered half-sibs. Among the 19 provenances there were a total of 93 families represented. The nuts were germinated and planted at Byron, GA, in 1989, and the collection process, experiment design, planting and management of the orchard has been described in detail elsewhere (Grauke et al. 1989; Wood et al. 1998; Rüter et al. 1999). Briefly, the seedlings were planted $(10.5 \mathrm{~m} \times 10.5 \mathrm{~m})$ in a completely randomized design incorporating 10 siblings from each of the five parent trees (families) within each of the 19 provenances (original number of trees was $\sim 960$, but several trees have died for various reasons) (Wood et al. 1998). Part of the provenance collection was transplanted in 2007 to a site approximately $800 \mathrm{~m}$ from the first orchard (as described in Bock et al. 2016a), but site characteristics and tree management were the same at both locations and was typical for pecans in GA (Wells et al. 2018), although no fungicides or other pesticides were applied. Trees from the entire provenance collection at both sites were irrigated.

\section{Provenance location geographic variables, provenance tree characteristics and weather at Byron, GA, USA}

The geographic features of each provenance site of origin were previously characterized (Wood et al. 1998; Bock et al. 2016a) (Table 1). These included latitude, elevation, rainfall, mean temperature, minimum temperature [precipitation data obtained from NOAA (1986) and Garcia de Miranda et al. (1980) for the USA and Mexico, respectively, and temperature data from the USDA Plant Hardiness Zone Map (Wood et al. 1998)], and some provenance tree-related characters including date of budbreak (date of first appearance of inner bud scale split on the exterior canopy), leaflet droop angle, and leaflet tilt angle, as previously recorded (Wood et al. 1998). Droop angle is the angular distance between the abaxial planes of opposite leaflets at the center of a compound leaf (flat compound leaves have a large droop angle, while leaves that droop and form a "rib-cage" appearance have small droop angles). Leaflet tilt angle is the angular distance the plane of the base of leaflets project above the plane of the rachis of the compound leaf to which the leaflet is attached.

Weather data for the Macon Regional Airport $[9 \mathrm{~km}$ from the Byron location) was obtained from the National Oceanic and Atmospheric Administration, National Centers for Environmental Information, Climate Information, Climate Data Online (NOAA 2020)]. Monthly rainfall totals (March 1 to August 31) for 2018 and 2019, and for the long-term average 1949-2017 were used. For 


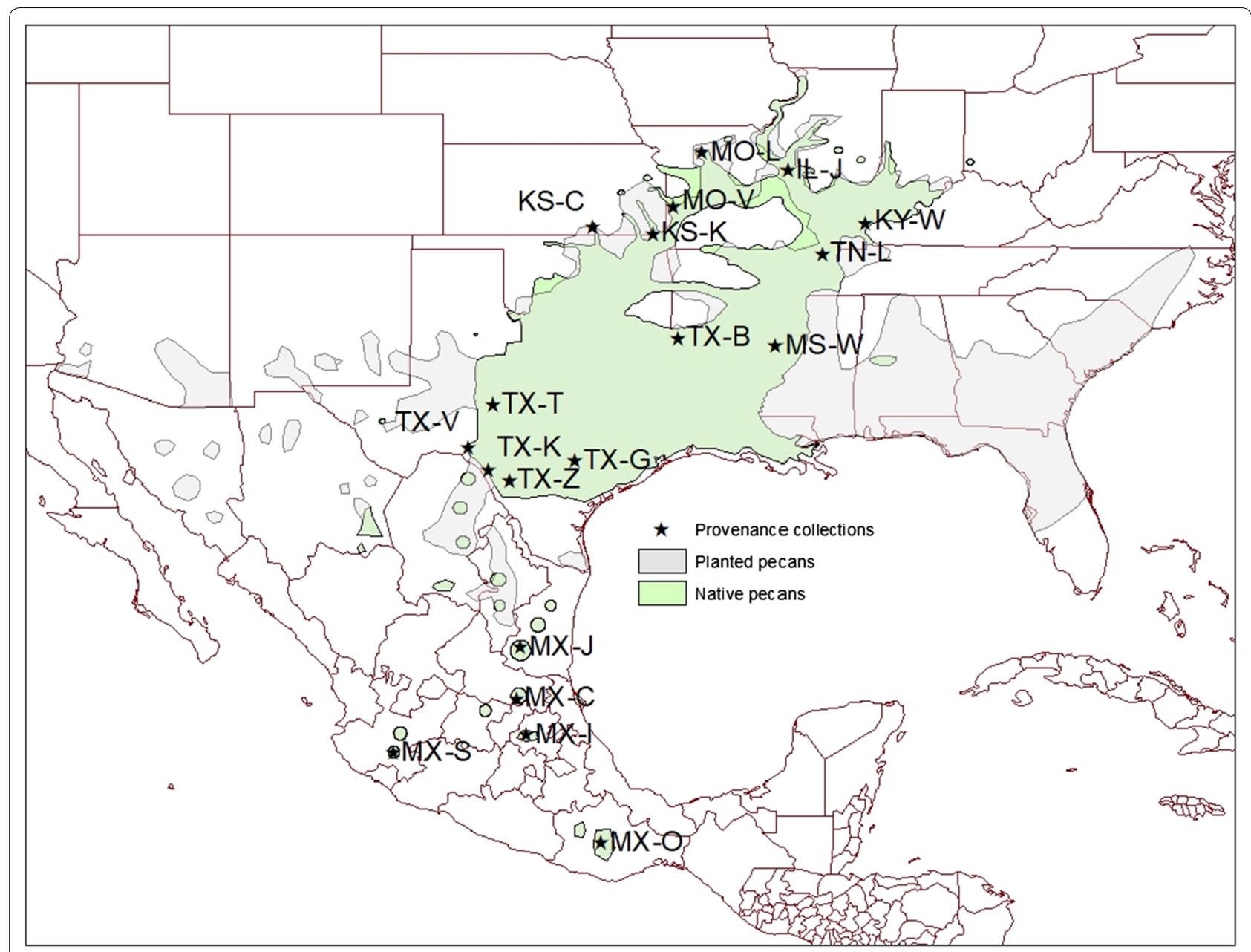

Fig. 1 Map showing the natural, native pecan distribution in the USA and Mexico, where pecan is cultivated, and the locations of the provenances used to collect nuts for planting. Details of the location names and specific trees are provided in Table 1

the long-term average the $95 \%$ confidence intervals were calculated. The spring and summer months are when scab is active and leaves and fruit are present and susceptible to infection.

\section{Scab assessment methods}

Assessments of scab on foliage and fruit were performed the same way in 2018 and 2019. In both years, a novel quantitative ordinal scale based on the percentage ratio scale (modified from Chiang et al. 2014; Bock et al. 2020) was used to speed up the process of assessment (Additional file 1: Table S1). The quantitative ordinal scale has 16 grades and was designed to be rapid but more discerning compared to the original 5-class Hunter-Roberts scale (Hunter and Roberts 1978) generally used for rating pecan scab. Several studies have shown that more grades can reduce the risk of type II errors (Chiang et al. 2014, 2016). A type II error is defined as the probability of accepting the null hypothesis $\left[\mathrm{H}_{0}\right]$ when $\mathrm{H}_{0}$ is false (in other words, a scale of lower resolution increases the risks of failing to reject the null hypothesis). The 16 grades of the scale can be assigned as ordinal numbers $(0$, $1,2,3, \ldots .15)$, or as the maximum of that percent interval range $(0,0.1,0.5,1, \ldots 0.100)$, which may be easier to use as it has a direct relation to the amount of disease on a leaf or fruit. Midpoint values of the intervals are used for subsequent parametric analysis. Two scab assessments were made on foliage and fruit: (1) a visual estimate of scab severity on the most severely scabbed leaf or fruit that could be observed in the canopy, and (2) a visual, overall mean scab severity estimate for all the leaves or fruit in the tree. Sample size for leaves was a visual inspection of the whole canopy to obtain an overall mean estimate. Fruit numbers varied from just a few to many per tree, but at least 20 fruit (or if fewer, as many as were present) were inspected and an overall mean estimated for scab severity. Both the maximum and overall mean assessments were performed by walking around 


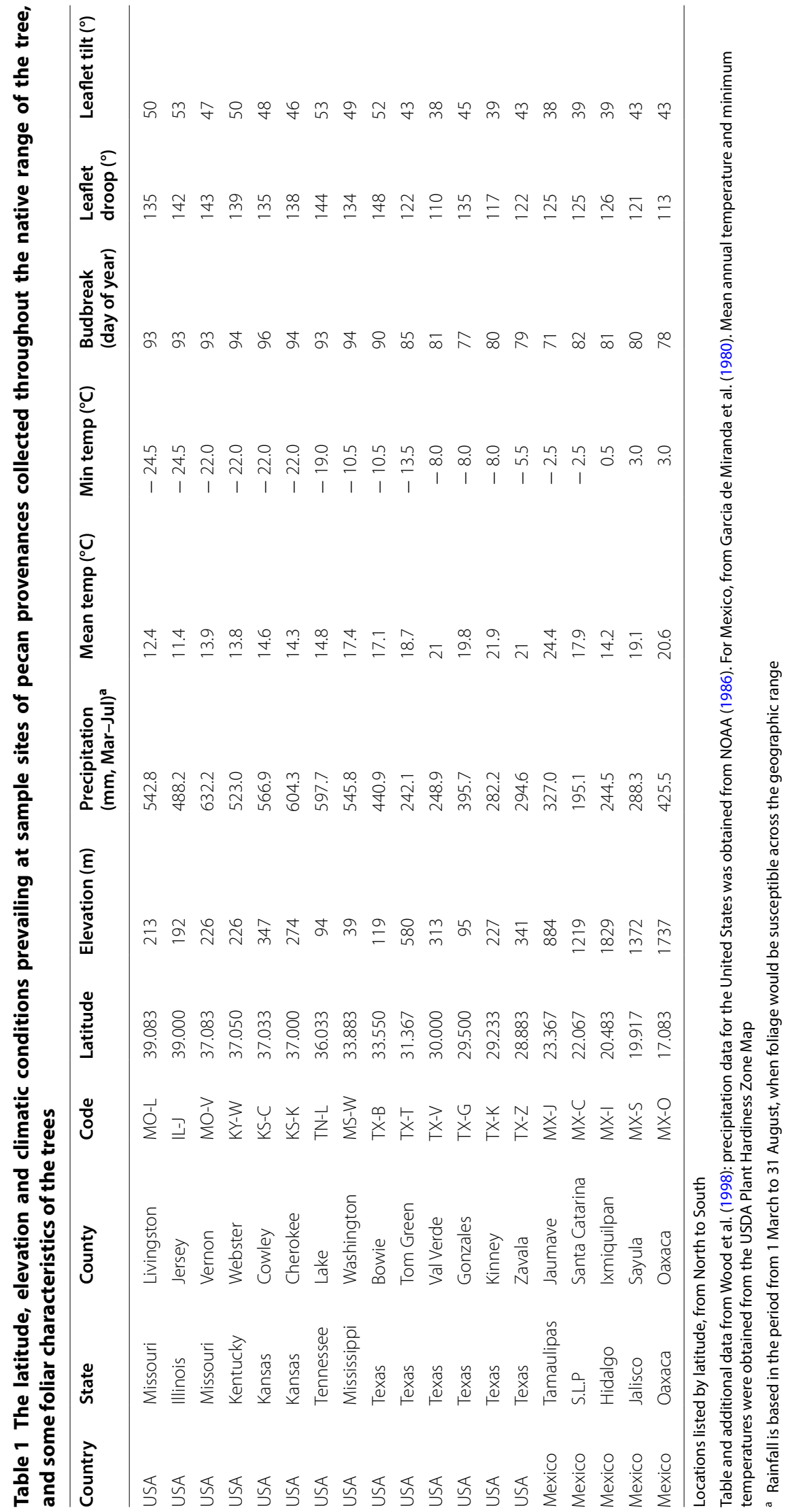


the tree to observe scab on leaves and fruit in the canopy. The two complementary estimates were made to explore if any noticeable impacts on the results exist to indicate a preferred approach to assessing scab in the future. In all cases, standard area diagrams (SADs) were used to aid estimates of scab severity on the most severely infected leaf (Bock, unpublished leaf SADs) and fruit (Yadav et al., 2013).

In 2018 and 2019, all 875 trees in the provenance collection were assessed for scab on foliage, but only 684 were assessed for fruit scab in 2018, and only 563 in 2019 (Additional file 1: Table S2). The numbers of trees in each family in each assessment are indicated. Due to alternate bearing, not all trees produce fruit every year (or necessarily the same trees), so the resulting lower numbers of trees assessed for fruit scab is not surprising. Depending on assessment, up to three individuals rated the trees for scab; in all cases the individuals received detailed instruction, were well-trained and well-experienced in rating pecan leaves and fruit for scab severity. Assessments were performed in the field and in 2018 were made on foliage between 21 June and 29 July, and on fruit between 9 and 24 August, and in 2019 were made on foliage between 9 and 11 July, and on fruit between 19 August and 27 September.

\section{Data analysis}

All scab severity data were natural $\log$ transformed (nlog $(0.1+$ severity $))$ to approximate to normality and ensure heterogeneity of variance. To determine effects of provenance alone on scab susceptibility, a mixed linear model with fixed effects of provenance and random effects of family nested in provenance and replicate nested in provenance was used individually for each year, assessment method and plant part (i.e., the same model was used for each of eight analyses for each of the response variables: one for each of the maximum and overall scab severity estimates on both foliage and fruit in both 2018 and 2019). The analysis reflects the fact that in the provenance analyses, families within provenances were not necessarily equally scab susceptible, the families are not the same for each provenance, and the replicates were considered the progeny-half sibs-of the trees within a single family. A second mixed linear model was used to analyze the fixed effects of family nested within provenance with random effects of replicate nested in provenance (as for provenance alone, the same model was used for the eight response variable analyses: one for each of the maximum and overall scab severity estimates on both foliage and fruit in 2018 and 2019). All mixed linear models were analyzed using maximum likelihood and computing the row-wise denominator degrees of freedom with a Kenward-Roger adjustment as degrees of freedom were not constant across least square mean differences. For all analyses a post hoc means comparison of the $\log$ transformed data for the provenance and family means was performed using a Tukey-Kramer test $(\alpha=0.05)$. The means separation was performed with a SAS macro (PDMIX800) which takes the probability values for differences among means and converts these to letter groups; means with a common letter are not statistically different (Saxton 1998). Subsequent to the post hoc analysis, the data were back transformed. The 95\% CIs were also back transformed and are presented.

For both the provenance means and the family within provenance means an Unweighted Paired Grouping of Mathematical Averages (UPGMA) cluster analysis was performed to assess the relationships in the 2 years and on leaves and fruit using the maximum and overall severity assessments (Sokal and Michener 1958; Sneath and Sokal 1973).

In addition, and to provide further insights, the provenance and family mean scab severities were ranked from 1 to 19 and 1 to 93, respectively, based on magnitude of severity for further comparisons between assessments on both leaves and fruit (done for both maximum and overall severities) and for both years. Correlation analysis was performed to explore the associations between rankings of provenances and families within provenances among the various assessments and years and between geographic variables, plant characteristics and scab severity for each assessment on leaves and fruit. Correlation analysis was used to compare the provenance and family ratings taken in this study to those obtained in 1998, 2013 and 2014 (Bock et al. 2016a). Spearman's rank correlation was used for ordinal scale data (based on the numeric values of the scale, in this case the 1 to 5 scale ratings of the Hunter-Roberts scale), but Pearson's correlation was used for continuous data (either actual percentage estimates, or those based on mid-point values of the severity estimates in percent). Due to non-independence of data, associations of individual tree assessments between years were not subject to correlation analysis. A stepwise multiple regression was performed to further explore the predictive ability of source provenance geographical factors (latitude, rainfall, mean maximum and mean minimum temperatures, and elevation) and provenance tree characteristics (budbreak date, leaflet droop angle and leaflet tilt angle) on severity of scab (for each year, plant part and assessment year) as the response variable.

Heritability (Wright 1976; Holland et al. 1998) is the proportion of phenotypic variance that can be attributed to genetic factors. The heritability depends on population-specific factors including allele frequencies, effects of gene variants, and environmental factor effects. In this case we calculated broad-sense heritability, defined as 
$\mathrm{H}_{2}=\mathrm{V}_{\mathrm{G}} / \mathrm{V}_{\mathrm{P}}$ (where $\mathrm{V}_{\mathrm{G}}=$ genetic variance and $\mathrm{V}_{\mathrm{P}}=$ total phenotypic variance), which captures the proportion of phenotypic variation from genetic sources including effects due to dominance and epistasis. Heritability was calculated using a linear mixed model as described above, but with all sources modeled as random effects. Variance components of the model were obtained and used to estimate heritability as described in Holland et al. (1998), and were used to calculate heritability for both individual trees and families. Trees in the same family were assumed to be half-sibs as selfing in maternal trees was unlikely due to broad outcrossing in pecan (Wood et al. 1998). Due to trees being tested at a single location, no separation of genotype-environment interactions was possible, so it is possible that heritability is slightly overestimated (Wright 1976). All analyses were performed using SAS V9.4 (SAS Institute, Cary, NC, USA).

\section{Results}

Rainfall from March to August in 2018 and 2019 deviated from the long-term mean at the location and differed from each other (Additional file 1: Fig. S1). In 2018, rainfall $(74.2 \mathrm{~cm})$ exceeded the long-term average $(60.4 \mathrm{~cm})$, while in 2019 it was lower $(50.3 \mathrm{~cm})$. The year 2019 was drier through the spring and summer, although in August there was more than double the rainfall in 2019 compared to 2018. May in 2018 had more than twice the mean annual rainfall, providing moisture conducive to scab disease to proliferate on the developing foliage. Overall, both 2018 and 2019 had sufficient rainfall conducive for mild to moderate scab development on foliage and fruit, with 2018 being more conducive to severe scab.

\section{Provenance, scab susceptibility on leaves and fruit, and rating method}

Based on the tree assessment data, scab was observed on leaves of at least some trees from all provenances in both 2018 and 2019. The effect of provenance on the most severely scabbed leaf was significant in both 2018 $(\mathrm{F}=21.8, \quad \mathrm{P}<0.0001)$ and $2019 \quad(\mathrm{~F}=23.3, \quad \mathrm{P}<0.0001)$ (Table 2 and Additional file 1: Table S3). Similarly, provenance affected overall leaf scab severity rating in both $2018(\mathrm{~F}=13.7, \mathrm{P}<0.0001)$ and $2019(\mathrm{~F}=18.3, \mathrm{P}<0.0001)$. In both years, regardless of assessment (most severe scab or overall severity rating), the Tukey-Kramer least square means separation of the back transformed results showed trees from provenances in Texas and Mexico were either significantly or numerically the most susceptible (particularly provenances TX-K, TX-T, TX-V, TX-Z and MX-C). The UPGMA analysis gave similar results (Additional file 1: Fig. S2). Trees from provenances MX-I and MX-O tended to be susceptible or intermediate in foliar scab ratings. The provenances with trees most resistant to scab included TX-B, TX-G, MX-J, MX-S, TN-L, IL-J, MO-L, MO-V, MS-W, KY-W KS-K and KS-C. Most often the same provenances grouped together regardless of year (2018 or 2019) or assessment (most severe or overall severity). However, the number of groups based on a Tukey-Kramer means separation did vary and was six for the most severe scab in 2018, and five in 2019. For the overall scab severity, the ratings for 2018 separated in three groups and six groups in 2019. The ranking of the provenances by magnitude of mean scab severity showed that the ordering of provenances was similar, but individual provenances did shift by one or a few ranks in some cases depending on the year and the assessment method.

Based on the tree assessment data, scab was observed on fruit of at least some trees in all provenances in both 2018 and 2019. The effect of provenance on most severely scabbed fruit was significant in both $2018(\mathrm{~F}=21.2$, $\mathrm{P}<0.0001)$ and $2019(\mathrm{~F}=28.4, \mathrm{P}<0.0001)$ (Table 3 and Additional file 1: Table S3). Similarly, tree provenance affected overall fruit scab severity rating in both 2018 $(\mathrm{F}=21.6, \mathrm{P}<0.0001)$ and $2019(\mathrm{~F}=26.8, \mathrm{P}<0.0001)$. In both years, regardless of assessment (most severe or overall severity rating), and as with the leaf assessments, the Tukey-Kramer least square means separation of the back transformed results showed trees in provenances from Texas and Mexico were either significantly or numerically the most susceptible (TX-K, TX-T, TX-V, TX-Z, MX-C, MX-I, MX-O and MX-S). The UPGMA analysis gave similar results (Additional file 1: Fig. S3). The provenances with fruit most resistant to scab included TX-B, TN-L, IL-J, MO-L, MO-V, MS-W, KY-W KS-K. Fruit on trees from provenances MX-I, MX-J, TX-G, and KS-C were either inconsistent in grouping or intermediate in scab susceptibility. Most often, the same provenances grouped together regardless of year or assessment (most severe or overall severity). However, the number of groups based on the Tukey-Kramer means separation did vary and was seven for the most severe scab in 2018, and five in 2019. For the overall scab severity, there were five groups in 2018 and only three groups in 2019. As with the foliage ratings, the ranking of provenances by mean scab severity showed that most often they followed similar orders, although provenances may shift by one or a few ranks in some cases depending on year and assessment method.

The correlation analysis of assessments of the rankings of foliar and fruit scab confirmed all were highly correlated. For assessments of foliar scab the correlations ( $\mathrm{r}$ ) ranged from 0.853 to 0.988 (all $\mathrm{P}<0.0001$ ) (Table 4, below the diagonal, and Additional file 1: Fig. S4). The correlation analysis of fruit assess scab rankings were also highly correlated ranging from 0.911 to 0.986 (all $\mathrm{P}<0.0001$ ). Finally, there were strong correlations between the foliage 
Table 2 Severity of scab on pecan leaves by provenance in 2018 and 2019 at Byron, GA, USA

\begin{tabular}{|c|c|c|c|c|c|c|c|c|}
\hline \multirow[t]{3}{*}{ Provenance } & \multicolumn{4}{|l|}{ Most scabbed } & \multicolumn{4}{|l|}{ Overall } \\
\hline & \multicolumn{2}{|l|}{2018} & \multicolumn{2}{|l|}{2019} & \multicolumn{2}{|l|}{2018} & \multicolumn{2}{|l|}{2019} \\
\hline & $\%$ severity $^{\mathrm{a}}$ (rank) & $95 \% \mathrm{Cl}$ & $\%$ severity (rank) & $95 \% \mathrm{Cl}$ & $\%$ severity (rank) & $95 \% \mathrm{Cl}$ & $\%$ severity (rank) & $95 \% \mathrm{Cl}$ \\
\hline IL-J & $0.12 \mathrm{~F}^{b}(18)^{c}$ & $0.07-0.19$ & $0.1 \mathrm{E}(19)$ & $0.07-0.15$ & $0.11 C(16)$ & $0.09-0.14$ & $0.1 F(19)$ & $0.09-0.12$ \\
\hline $\mathrm{KS}-\mathrm{C}$ & 0.21 CDEF (10) & $0.12-0.38$ & $0.14 \mathrm{DE}(9)$ & $0.09-0.23$ & 0.14 BC (9) & $0.1-0.19$ & $0.12 \mathrm{DEF}(10)$ & $0.1-0.14$ \\
\hline KS-K & 0.14 DEF (13) & $0.08-0.25$ & $0.11 \mathrm{E}(14)$ & $0.07-0.17$ & 0.12 BC (14) & $0.09-0.16$ & $0.11 \mathrm{EF}(14)$ & $0.09-0.13$ \\
\hline KY-W & $0.13 \mathrm{DEF}(15)$ & $0.07-0.24$ & $0.11 \mathrm{E}(15)$ & $0.07-0.17$ & $0.12 \mathrm{BC}(15)$ & $0.09-0.16$ & $0.11 \mathrm{EF}(16)$ & $0.09-0.13$ \\
\hline MO-L & $0.12 \mathrm{EF}(17)$ & $0.07-0.22$ & $0.11 \mathrm{E}(12)$ & $0.07-0.18$ & 0.11 BC (19) & $0.08-0.15$ & $0.11 \mathrm{DEF}(11)$ & $0.09-0.14$ \\
\hline $\mathrm{MO}-\mathrm{V}$ & $0.13 \mathrm{EF}(16)$ & $0.07-0.22$ & $0.11 \mathrm{E}(13)$ & $0.07-0.17$ & $0.11 \mathrm{BC}(18)$ & $0.08-0.15$ & $0.11 \mathrm{EF}(13)$ & $0.09-0.13$ \\
\hline MS-W & 0.17 DEF (11) & $0.09-0.34$ & $0.11 \mathrm{E}(16)$ & $0.06-0.18$ & $0.12 \mathrm{BC}(13)$ & $0.09-0.17$ & $0.11 \mathrm{EF}(15)$ & $0.09-0.13$ \\
\hline$M X-C$ & 0.98 ABC (5) & $0.52-1.86$ & $0.42 \mathrm{BCD}(7)$ & $0.25-0.69$ & $0.24 \mathrm{AB}(5)$ & $0.17-0.34$ & 0.17 BCDE (6) & $0.14-0.2$ \\
\hline$M X-1$ & 0.49 CDE (7) & $0.29-0.81$ & $0.46 \mathrm{BC}(6)$ & $0.31-0.7$ & $0.19 \mathrm{BC}(7)$ & $0.14-0.24$ & 0.17 BCD (5) & $0.15-0.2$ \\
\hline MX-J & 0.16 DEF (12) & $0.1-0.27$ & $0.12 \mathrm{E}(11)$ & $0.08-0.18$ & $0.12 \mathrm{BC}(11)$ & $0.1-0.16$ & $0.11 \mathrm{EF}(12)$ & $0.1-0.13$ \\
\hline MX-O & 0.68 BCD (6) & $0.35-1.33$ & 0.25 CDE (8) & $0.15-0.42$ & $0.21 \mathrm{ABC}(6)$ & $0.15-0.29$ & 0.15 CDEF (8) & $0.12-0.18$ \\
\hline MX-S & 0.22 CDEF (9) & $0.11-0.45$ & $0.53 \mathrm{ABC}(5)$ & $0.32-0.88$ & 0.13 BC (10) & $0.09-0.18$ & 0.16 BCDEF (7) & $0.13-0.2$ \\
\hline TN-L & $0.11 F(19)$ & $0.07-0.2$ & $0.1 \mathrm{E}(17)$ & $0.07-0.16$ & 0.11 BC (17) & $0.08-0.15$ & 0.1 EF (18) & $0.09-0.12$ \\
\hline TX-B & $0.14 \mathrm{EF}(14)$ & $0.08-0.23$ & $0.1 \mathrm{E}(18)$ & $0.07-0.16$ & $0.12 \mathrm{BC}(12)$ & $0.09-0.16$ & $0.1 F(17)$ & $0.09-0.12$ \\
\hline TX-G & 0.28 CDEF (8) & $0.16-0.47$ & $0.14 \mathrm{DE}(10)$ & $0.09-0.21$ & 0.15 BC (8) & $0.11-0.2$ & $0.12 \mathrm{DEF}(9)$ & $0.1-0.14$ \\
\hline TX-K & $2.77 \mathrm{AB}(2)$ & $1.66-4.61$ & 1.38 A (3) & $0.92-2.07$ & $0.41 \mathrm{~A}(2)$ & $0.32-0.54$ & $0.22 \mathrm{ABC}(3)$ & $0.19-0.26$ \\
\hline TX-T & 4.09 A (1) & $2.47-6.77$ & $1.4 \mathrm{~A}(2)$ & $0.94-2.1$ & $0.41 \mathrm{~A}(3)$ & $0.31-0.53$ & $0.25 \mathrm{AB}(2)$ & $0.21-0.29$ \\
\hline TX-V & $2.71 A B(3)$ & $1.59-4.61$ & $1.63 \mathrm{~A}(1)$ & $1.07-2.48$ & $0.42 \mathrm{~A}(1)$ & $0.32-0.55$ & $0.32 \mathrm{~A}(1)$ & $0.27-0.37$ \\
\hline$T X-Z$ & $2.13 \mathrm{AB}(4)$ & $1.25-3.62$ & $0.86 \mathrm{AB}(4)$ & $0.57-1.3$ & $0.4 \mathrm{~A}(4)$ & $0.31-0.53$ & 0.21 BC (4) & $0.18-0.24$ \\
\hline F value $(P)$ & $21.8(<0.0001)$ & & $23.3(<0.0001)$ & & $13.7(<0.0001)$ & & $18.3(<0.0001)$ & \\
\hline
\end{tabular}

In both years two scab severity estimates were taken, (1) a visual assessment of the most severely scabbed leaf, and (2) an overall assessment of the severity on leaves in the tree canopy. Estimates were based on a quantitative ordinal scale taking interval mid-points prior to analysis (Chiang et al. 2014)

a The $\%$ area diseased estimates were natural log transformed. Back transformed values are presented with means separation based on transformed values. The $95 \%$ $\mathrm{Cls}$ are back transformed values such that the upper confidence limit is EXP(LNmean + LNupperCl), and the lower confidence limit is EXP(LNmean - LNlower)

b Means separation was based on the Tukey-Kramer method $(a=0.05)$

c Rank is the ranking order of magnitude from highest severity to lowest severity

and the fruit rankings of susceptibility, regardless of year or assessment method ( $r=0.786$ to 0.951 , all $\mathrm{P}<0.0001)$.

\section{Family, scab susceptibility and rating method}

Based on the tree assessment data, no scab was observed on the foliage of any trees in one family (KS-C-1) in 2018, a more severe scab year, and nine families (KS-C-1, KY-W-1, KY-W-2, MO-V-1, MS-W-1, MS-W-3, TN-L3, TN-L-6, and TX-B-5) in 2019. No scab was observed on fruit of any tree in ten (KS-C-1, MO-L-4, MS-W-1, MS-W-4, MS-W-5, TN-L-1, TN-L-4,TN-L-6, TX-B-2 and TX-V-4) families in 2018, and on twenty-five families (IL-J-1, IL-J-2, IL-J-3, IL-J-4, KS-C-1, KS-C-4, KS-K-3, KS-K-5, KY-W-1, KY-W-4, KY-W-5, MO-L-1, MO-L-4, MO-L-5, MS-W-1, MS-W-2, MS-W-4, MS-W-5, TN-L1, TN-L-4, TN-L-6, TX-B-2, TX-B-4, TX-B-5, and TX-G3 ) in 2019. The UPGMA cluster analysis for foliage with both the most severe scab (Fig. 2) and the overall tree severity (Fig. 3) and on fruit for both the most severe scab (Fig. 4) and the overall tree severity (Fig. 5) showed similar patterns in groupings. The mixed effects analysis of variance (ANOVA) showed family (within provenance) had a highly significant effect on the severity of foliar scab for both the most severe scab assessed (2018, $\mathrm{F}=1.9, \mathrm{P}<0.0001$, and 2019, $\mathrm{F}=2.7, \mathrm{P}<0.0001$, respectively), and the overall severity $(2018, \mathrm{~F}=2.0, \mathrm{P}<0.0001$, and 2019, $\mathrm{F}=1.7, \mathrm{P}<0.0001$, respectively) (Additional file 1: Table S3). Similarly, for fruit scab assessments, the effect of parent tree (within provenance) also had a highly significant effect on the severity of scab for both the most severe scab assessed (2018, $\mathrm{F}=2.2, \mathrm{P}<0.0001$, and 2019, $\mathrm{F}=2.4, \mathrm{P}<0.0001$, respectively), and the overall severity (2018, $\mathrm{F}=3.0, \mathrm{P}<0.0001$, and $2019, \mathrm{~F}=3.1$, $\mathrm{P}<0.0001$, respectively) (Additional file 1: Table S3). The Tukey-Kramer least square means separation of the back transformed results showed groupings of scab susceptibility among families within provenances and families between provenances (Additional file 1: Tables S4 and S5), although numerically the most resistant or susceptible (and those ranked as the most resistant or 
Table 3 Severity of scab on pecan fruit by provenance in 2018 and 2019 at Byron, GA, USA

\begin{tabular}{|c|c|c|c|c|c|c|c|c|}
\hline \multirow[t]{3}{*}{ Provenance } & \multicolumn{4}{|l|}{ Most scabbed } & \multicolumn{4}{|l|}{ Overall } \\
\hline & \multicolumn{2}{|l|}{2018} & \multicolumn{2}{|l|}{2019} & \multicolumn{2}{|l|}{2018} & \multicolumn{2}{|l|}{2019} \\
\hline & $\begin{array}{l}\text { \% severity } \\
\text { (rank) }\end{array}$ & $95 \% \mathrm{Cl}$ & $\%$ severity (rank) & $95 \% \mathrm{Cl}$ & $\%$ severity (rank) & $95 \% \mathrm{Cl}$ & $\%$ severity (rank) & $95 \% \mathrm{Cl}$ \\
\hline IL-J & $0.27 \mathrm{FG}^{\mathrm{b}}(14)^{\mathrm{c}}$ & $0.12-0.59$ & $0.11 \mathrm{E}(18)$ & $0.05-0.24$ & $0.19 E(13)$ & $0.09-0.4$ & $0.1 C(18)$ & $0.05-0.22$ \\
\hline $\mathrm{KS}-\mathrm{C}$ & 2.31 CDEF (9) & $0.88-6.05$ & $0.26 \mathrm{DE}(11)$ & $0.11-0.63$ & $0.6 \mathrm{CDE}(9)$ & $0.25-1.47$ & $0.19 C(11)$ & $0.08-0.45$ \\
\hline KS-K & 0.85 DEFG (10) & $0.32-2.24$ & $0.2 \mathrm{DE}(12)$ & $0.08-0.51$ & $0.31 \mathrm{DE}(10)$ & $0.13-0.78$ & $0.14 C(13)$ & $0.06-0.34$ \\
\hline KY-W & 0.24 FG (15) & $0.09-0.66$ & $0.15 \mathrm{DE}(15)$ & $0.06-0.39$ & $0.16 \mathrm{E}(15)$ & $0.06-0.39$ & 0.14 C (14) & $0.06-0.33$ \\
\hline MO-L & $0.23 \mathrm{FG}(16)$ & $0.07-0.69$ & $0.13 \mathrm{DE}(16)$ & $0.04-0.44$ & $0.12 \mathrm{E}(18)$ & $0.04-0.33$ & $0.1 C(17)$ & $0.03-0.33$ \\
\hline $\mathrm{MO}-\mathrm{V}$ & 0.59 DEFG (12) & $0.23-1.49$ & $0.17 \mathrm{DE}(13)$ & $0.07-0.43$ & $0.19 \mathrm{E}(14)$ & $0.08-0.44$ & $0.15 C(12)$ & $0.06-0.36$ \\
\hline MS-W & $0.19 \mathrm{FG}(17)$ & $0.06-0.58$ & $0.16 \mathrm{DE}(14)$ & $0.06-0.43$ & $0.16 \mathrm{E}(16)$ & $0.06-0.43$ & $0.11 C(15)$ & $0.04-0.3$ \\
\hline$M X-C$ & 19.27 ABC (5) & $6.94-53.52$ & $18.6 A B(6)$ & $7.37-46.92$ & $5.35 \mathrm{ABC}(5)$ & $2.07-13.82$ & $8.5 \mathrm{AB}(7)$ & $3.46-20.84$ \\
\hline$M X-I$ & 5.58 BCD (8) & $2.45-12.69$ & $6.19 \mathrm{BC}(8)$ & $2.94-13.04$ & $2.4 \mathrm{BCD}(8)$ & $1.09-5.26$ & 3.33 B (8) & $1.59-6.97$ \\
\hline$M X-J$ & 0.7 EFG (11) & $0.31-1.54$ & $0.86 \mathrm{D}(10)$ & $0.41-1.77$ & $0.27 \mathrm{E}(11)$ & $0.12-0.57$ & 0.44 C (9) & $0.22-0.92$ \\
\hline MX-O & $22.98 \mathrm{ABC}(4)$ & $7.49-70.54$ & $19.73 \mathrm{AB}(5)$ & $7.29-53.39$ & $5.13 \mathrm{ABC}(6)$ & $1.88-13.95$ & $8.53 \mathrm{AB}(6)$ & $3.34-21.77$ \\
\hline MX-S & 27.48 ABC (3) & $9.46-79.78$ & 29.36 AB (4) & $10.97-78.56$ & 8.89 AB (3) & $3.43-23.06$ & $13.96 \mathrm{AB}(4)$ & $5.54-35.19$ \\
\hline TN-L & 0.14 G (19) & $0.06-0.35$ & $0.12 \mathrm{DE}(17)$ & $0.05-0.29$ & $0.11 \mathrm{E}(19)$ & $0.05-0.25$ & $0.11 C(16)$ & $0.05-0.24$ \\
\hline TX-B & $0.19 \mathrm{G}(18)$ & $0.08-0.43$ & $0.1 \mathrm{E}(19)$ & $0.04-0.24$ & $0.12 E(17)$ & $0.05-0.26$ & 0.1 C (19) & $0.05-0.23$ \\
\hline TX-G & 0.5 EFG (13) & $0.22-1.15$ & 0.93 CD (9) & $0.43-2.03$ & $0.26 E(12)$ & $0.12-0.58$ & $0.36 C(10)$ & $0.17-0.78$ \\
\hline TX-K & $49.1 \mathrm{AB}(2)$ & $20.49-117.66$ & 49.65 A (1) & $21.74-113.4$ & 29.03 A (2) & $12.84-65.65$ & 33.95 A (1) & $15.27-75.49$ \\
\hline TX-T & $70.34 \mathrm{~A}(1)$ & $29.29-168.93$ & $38.11 \mathrm{AB}(2)$ & $16.14-90$ & $38.82 \mathrm{~A}(1)$ & $17.14-87.94$ & 22.43 AB (3) & $9.83-51.17$ \\
\hline TX-V & $6.93 \mathrm{ABCDE}(7)$ & $1.64-29.34$ & $32.85 \mathrm{AB}(3)$ & $7.42-145.41$ & $5.05 \mathrm{ABCD}(7)$ & $1.45-17.63$ & 27.27 AB (2) & $6.99-106.4$ \\
\hline$T X-Z$ & $16.63 \mathrm{ABC}(6)$ & $6.75-41$ & 15.58 AB (7) & $6.18-39.27$ & $5.89 \mathrm{AB}(4)$ & $2.55-13.62$ & $9.12 \mathrm{AB}(5)$ & $3.77-22.04$ \\
\hline F value $(P)$ & $21.2(<0.0001)$ & & $28.4(<0.0001)$ & & $21.6(<0.0001)$ & & $26.8(<0.0001)$ & \\
\hline
\end{tabular}

In both years two scab severity estimates were taken, (1) a visual assessment of the most severely scabbed fruit, and (2) an overall assessment of the severity on fruit in the tree canopy. Estimates were based on a quantitative ordinal scale taking interval mid-points prior to analysis (Chiang et al. 2014)

a The $\%$ area diseased estimates were natural log transformed. Back transformed values are presented with means separation based on transformed values. The $95 \%$ $\mathrm{Cls}$ are back transformed values such that the upper confidence limit is EXP( $(\mathrm{Nmmean}+\mathrm{LNupperCl})$, and the lower confidence limit is EXP(LNmean - LNlower)

b Means separation was based on the Tukey-Kramer method $(a=0.05)$

c Rank is the ranking order of magnitude from highest severity to lowest severity

susceptible) were reasonably consistent among years and assessment methods, even if the ranking did vary somewhat. The Tukey-Kramer means separation found 14 groupings for the most severely scabbed and eleven groupings for overall scab severity score on foliage in 2018 with 12 and 11 groups for those scorings in 2019, respectively. For the most severely scabbed and overall scab severity score on fruit in 2018 , the ratings sorted into 12 and 11 distinct groups, respectively, and into nine and 12 in 2019, respectively. Thus, based on ranking and grouping of families within provenances using the most severe and the overall severity on foliage among the 20 most resistant families for each assessment, the most consistently resistant (referring to those ranked in the most resistant in three or more of the assessments) were IL-J-1, IL-J-3, KS-C-1, KY-W-2, MO-V-1, TN-L1, TN-L-3, TN-L-4, TX-B-2, and TX-B-5 (Additional file 1: Table S6). Conversely, among the 20 most susceptible families within each assessment (referring to those in the most susceptible grouping in three or more of the assessments) included MX-C-1, MX-I-2, MX-O-5, TX-K1, TX-K-4, TX-T-2, TX-T-3, TX-T-5, TX-V-1, TX-V-2, TX-V-3, TX-V-4, TX-V-5, TX-Z-2, TX-Z-4, and TX-Z-5. Based on ranking and grouping of families within provenances using the most severe and the overall severity on fruit among the 20 most resistant families for each assessment, the most consistently resistant (referring to those ranked in the most resistant in three or more of the assessments) were IL-J-1, KS-C-1, KY-W-5, MO-L-1, MO-L-4, MS-W-1, MS-W-2, MS-W-4, TN-L-1, TN-L-4, TN-L-6, TX-B-2, TX-B-4, TX-B-5, and TX-G-3. Similarly, the most consistently susceptible families within provenances based on fruit scab severity assessments (referring to those ranked in the most susceptible in three or more of the assessments) were MX-C-1, MX-I2, MX-O-3, MX-S-2, MX-S-5, TX-K-1, TX-K-4, TX-K5, TX-K-6, TX-T-1, TX-T-2, TX-T-4, TX-T-5, TX-V-1, and TX-V-3. Other families fluctuated more in ranking depending on the assessment, plant part rated and year. 
Table 4 Pearson's correlation analysis of mean scab severity rankings ${ }^{a}$ for provenances (below diagonal) and families within provenances (above diagonal) of pecan genotypes collected in 19 different provenances

\begin{tabular}{|c|c|c|c|c|c|c|c|c|c|}
\hline & & \multicolumn{8}{|c|}{ Family in provenance } \\
\hline & & $\begin{array}{l}\text { MS Leaf } \\
2018\end{array}$ & $\begin{array}{l}\text { MS Leaf } \\
2019\end{array}$ & $\begin{array}{l}\text { OS Leaf } \\
2018\end{array}$ & $\begin{array}{l}\text { OS Leaf } \\
2019\end{array}$ & $\begin{array}{l}\text { MS Fruit } \\
2018\end{array}$ & $\begin{array}{l}\text { MS Fruit } \\
2019\end{array}$ & $\begin{array}{l}\text { OS Fruit } \\
2018\end{array}$ & OS Fruit 2019 \\
\hline \multirow[t]{16}{*}{ Provenance } & \multirow{2}{*}{$\begin{array}{l}M^{b} \text { Leaf } \\
2018\end{array}$} & & 0.799 & 0.950 & 0.813 & 0.685 & 0.798 & 0.685 & 0.793 \\
\hline & & & $<0.0001$ & $<0.0001$ & $<0.0001$ & $<0.0001$ & $<0.0001$ & $<0.0001$ & $<0.0001$ \\
\hline & \multirow[t]{2}{*}{ MS Leaf 2019} & 0.896 & & 0.758 & 0.967 & 0.768 & 0.850 & 0.781 & 0.856 \\
\hline & & $<0.0001$ & & $<0.0001$ & $<0.0001$ & $<0.0001$ & $<0.0001$ & $<0.0001$ & $<0.0001$ \\
\hline & \multirow[t]{2}{*}{ OS Leaf 2018} & 0.968 & 0.853 & & 0.769 & 0.658 & 0.761 & 0.660 & 0.744 \\
\hline & & $<0.0001$ & $<0.0001$ & & $<0.0001$ & $<0.0001$ & $<0.0001$ & $<0.0001$ & $<0.0001$ \\
\hline & \multirow[t]{2}{*}{ OS Leaf 2019} & 0.918 & 0.988 & 0.867 & & 0.750 & 0.823 & 0.757 & 0.823 \\
\hline & & $<0.0001$ & $<0.0001$ & $<0.0001$ & & $<0.0001$ & $<0.0001$ & $<0.0001$ & $<0.0001$ \\
\hline & \multirow{2}{*}{$\begin{array}{c}\text { MS Fruit } \\
2018\end{array}$} & 0.840 & 0.875 & 0.786 & 0.846 & & 0.884 & 0.976 & 0.888 \\
\hline & & $<0.0001$ & $<0.0001$ & $<0.0001$ & $<0.0001$ & & $<0.0001$ & $<0.0001$ & $<0.0001$ \\
\hline & \multirow{2}{*}{$\begin{array}{l}\text { MS Fruit } \\
2019\end{array}$} & 0.918 & 0.944 & 0.867 & 0.925 & 0.932 & & 0.868 & 0.985 \\
\hline & & $<0.0001$ & $<0.0001$ & $<0.0001$ & $<0.0001$ & $<0.0001$ & & $<0.0001$ & $<0.0001$ \\
\hline & \multirow[t]{2}{*}{ OS Fruit 2018} & 0.874 & 0.867 & 0.837 & 0.839 & 0.982 & 0.921 & & 0.882 \\
\hline & & $<0.0001$ & $<0.0001$ & $<0.0001$ & $<0.0001$ & $<0.0001$ & $<0.0001$ & & $<0.0001$ \\
\hline & \multirow[t]{2}{*}{ OS Fruit 2019} & 0.896 & 0.951 & 0.863 & 0.919 & 0.914 & 0.986 & 0.911 & \\
\hline & & $<0.0001$ & $<0.0001$ & $<0.0001$ & $<0.0001$ & $<0.0001$ & $<0.0001$ & $<0.0001$ & \\
\hline
\end{tabular}

Matrix plots of the data are available as Additional file 1: Figures S4 and S5 Matrix plots of the data are available as Additional file 1: Figures S4 and S5

a Scab severity was visually estimated based on a modified ordinal scale (Chiang et al. 2014). MS=Most severe based on severity estimate of the most scabbed leaf or fruit; $O S=$ Overall severity based on an assessment of the overall disease on all leaves or fruit in the canopy

Family within provenance rankings for foliar scab severity were highly correlated $(r=0.758$ to 0.967 , all $\mathrm{P}<0.0001$ ) (Table 4, correlations above the diagonal, and Additional file 1: Fig. S5), as were the family within provenance ranking for fruit scab severity $(r=0.868$ to 0.976 all $\mathrm{P}<0.0001)$. Furthermore, very strong associations existed between the foliage rankings of susceptibility and the fruit rankings of susceptibility, regardless of year or assessment method $(\mathrm{r}=0.685$ to 0.856 , all $\mathrm{P}<0.0001)$.

A total of 201 trees had no scab observed in either year on either leaves or fruit, either based on the most severely infected, or an overall tree severity score (Additional file 1: Table S7). An additional 116 trees were free of disease on foliage but did not produce fruit in either year.

Each of the assessments for severity of scab in 2018 and 2019 was compared to the foliage ratings from 1998, 2013 and 2014 (Bock et al. 2016a) on the same trees (in the first seven replicates) for provenance and family in provenance using correlation analysis. In all cases the correlation between assessments was high and highly significant (for provenance, $\mathrm{r}=0.722$ to $0.954, \mathrm{P}<0.0001$ to 0.0005 ; for family within provenance, $r=0.494$ to 0.827 , all $\mathrm{P}<0.0001$ ) (Table 5).

\section{Provenance susceptibility in relation to geographic} and tree features

The latitude of the provenance origin was not associated with any measure of scab severity in either year (Table 6, Additional file 1: Fig. S6). Consistently negative associations were found between all assessments of scab severity and rainfall at the provenance origin. Specifically, if the provenance of origin rainfall was high, scab severity on those trees was low. Mean temperature at provenance origin was most often positively associated with scab severity (except the overall severity on fruit in 2018). Minimum temperature was positively associated only with most severe scab in 2019. The mean provenance budbreak date was negatively associated with overall severity of scab in 2018 and 2019 only (more severe scab developed on those trees from provenances with earlier budbreak dates), but leaf droop angle was consistently negatively associated with all scab severity ratings in both years. Similarly, scab severity was negatively associated with leaflet tilt angle except the overall severity of scab on fruit in 2018.

Stepwise multiple regression of the geographic features at the provenance source location and certain tree variables could predict the scab severity of trees from that provenance $(\mathrm{F}=4.8$ to $31.9, \mathrm{P}<0.0001$ to 0.02 ) (Additional file 1: Table S8). The beta coefficients $(-0.43$ to 


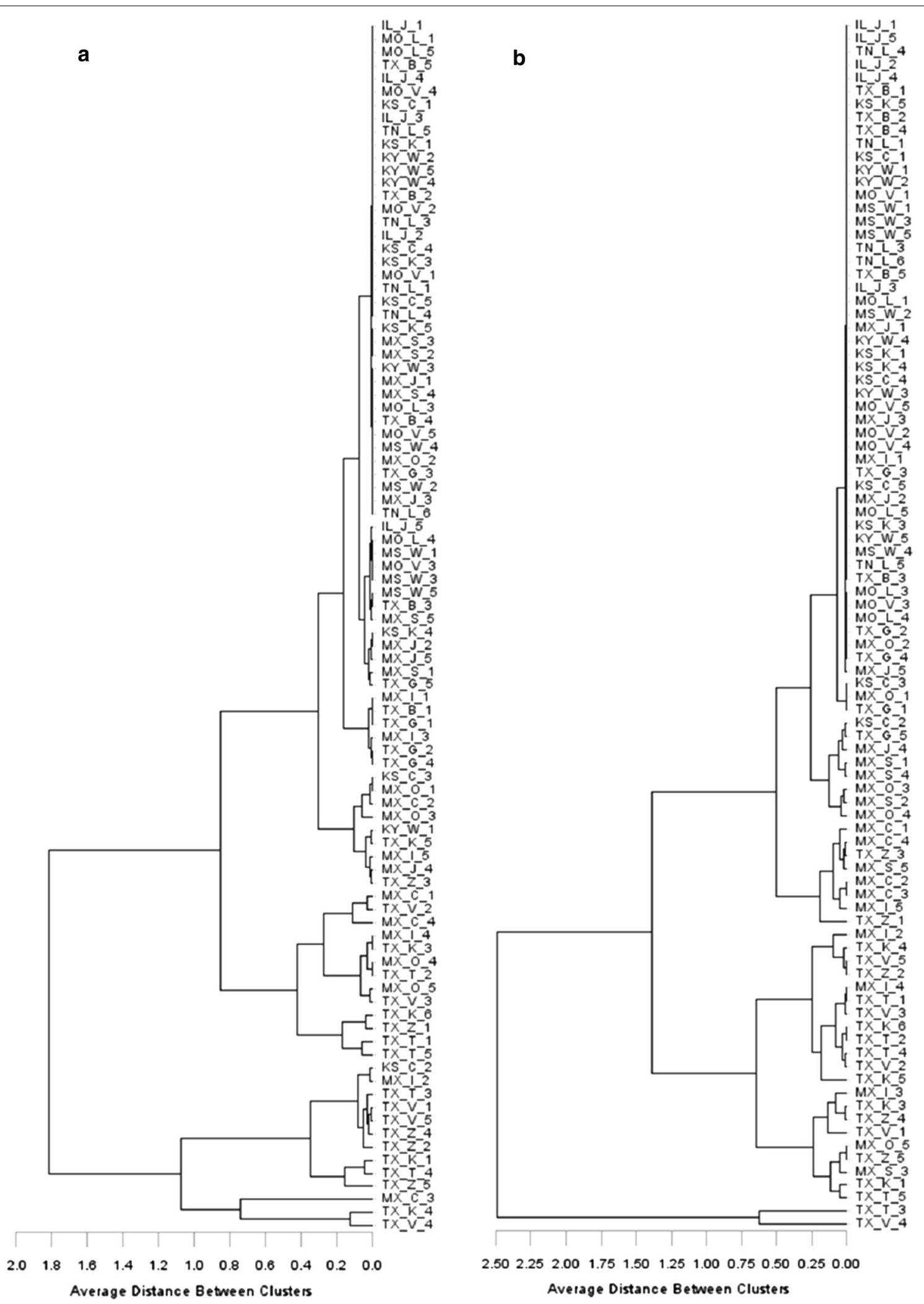

Fig. 2 UPGMA analysis of severity of scab (most severe rating) on pecan leaves by family within provenance in 2018 (a) and 2019 (b) at Byron, GA, USA. Estimates were based on a quantitative ordinal scale taking interval mid-points prior to analysis (Chiang et al. 2014) 


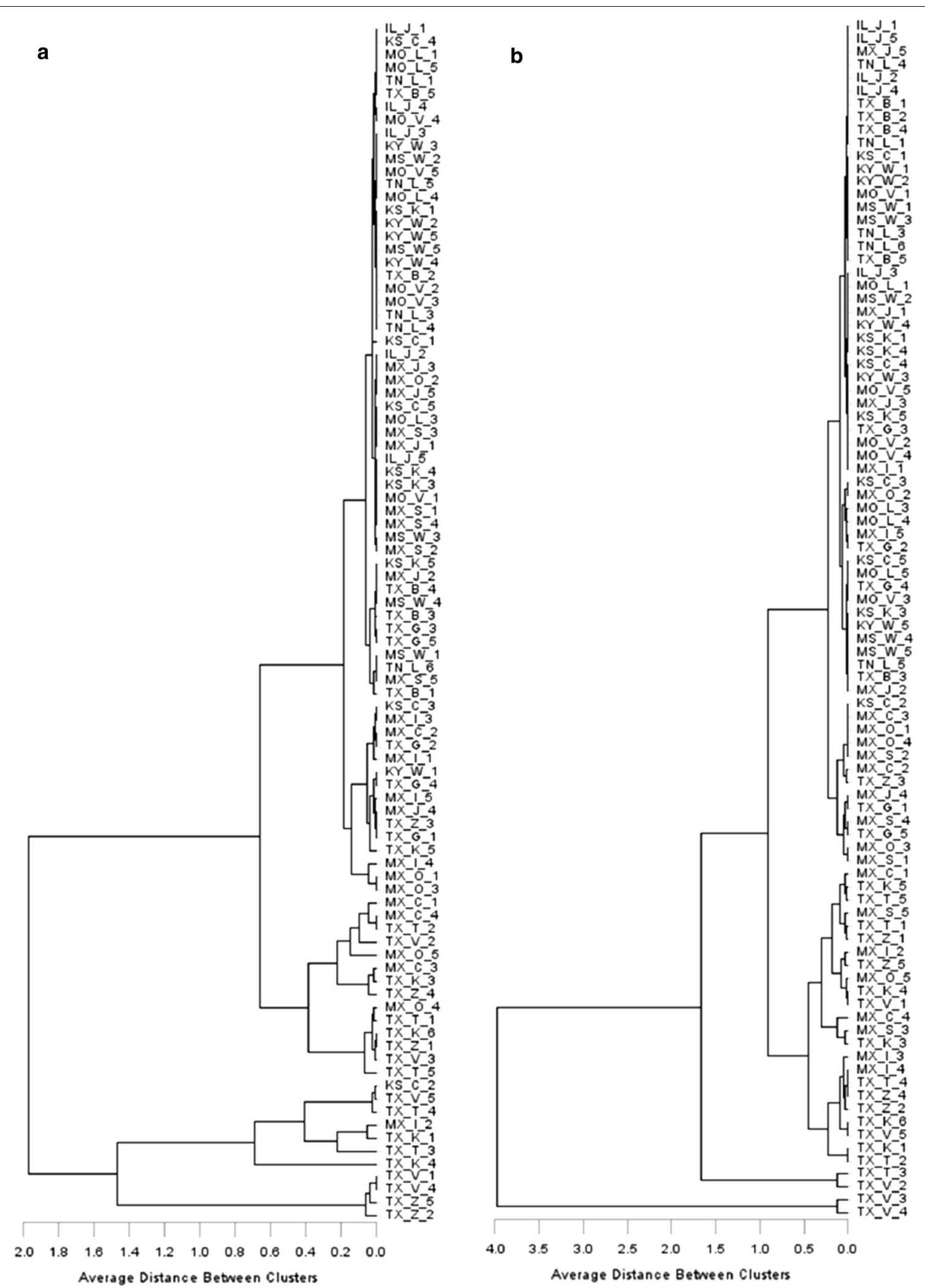

Fig. 3 UPGMA analysis of severity of scab (overall severity rating) on pecan leaves by family within provenance in 2018 (a) and 2019 (b) at Byron, GA, USA. Estimates were based on a quantitative ordinal scale taking interval mid-points prior to analysis (Chiang et al. 2014) 


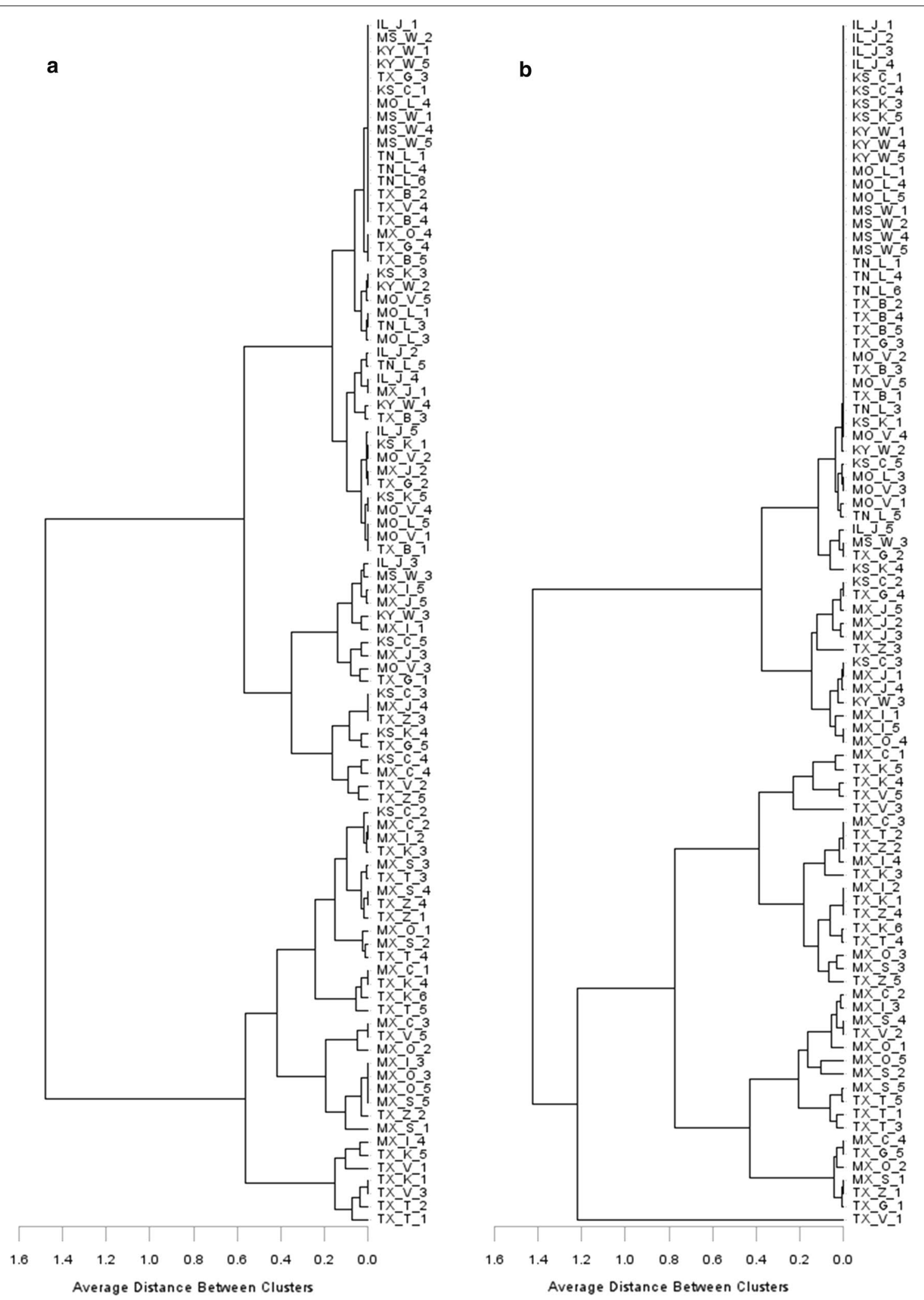

Fig. 4 UPGMA analysis of severity of scab (most severe rating) on pecan fruit by family within provenance in 2018 (a) and 2019 (b) at Byron, GA, USA. Estimates were based on a quantitative ordinal scale taking interval mid-points prior to analysis (Chiang et al. 2014) 


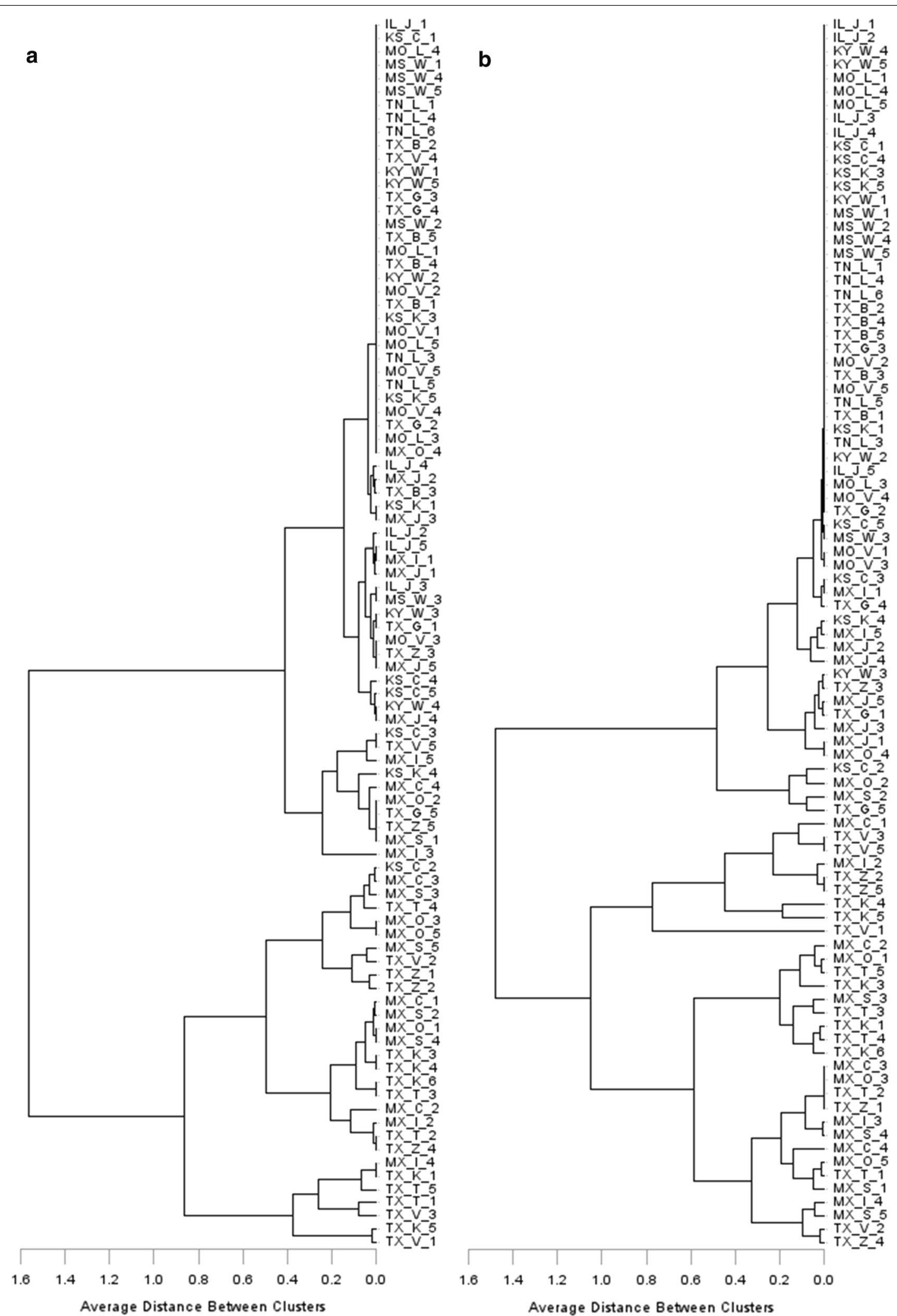

Fig. 5 UPGMA analysis of severity of scab (overall severity rating) on pecan fruit by family within provenance in 2018 (a) and 2019 (b) at Byron, GA, USA. Estimates were based on a quantitative ordinal scale taking interval mid-points prior to analysis (Chiang et al. 2014) 


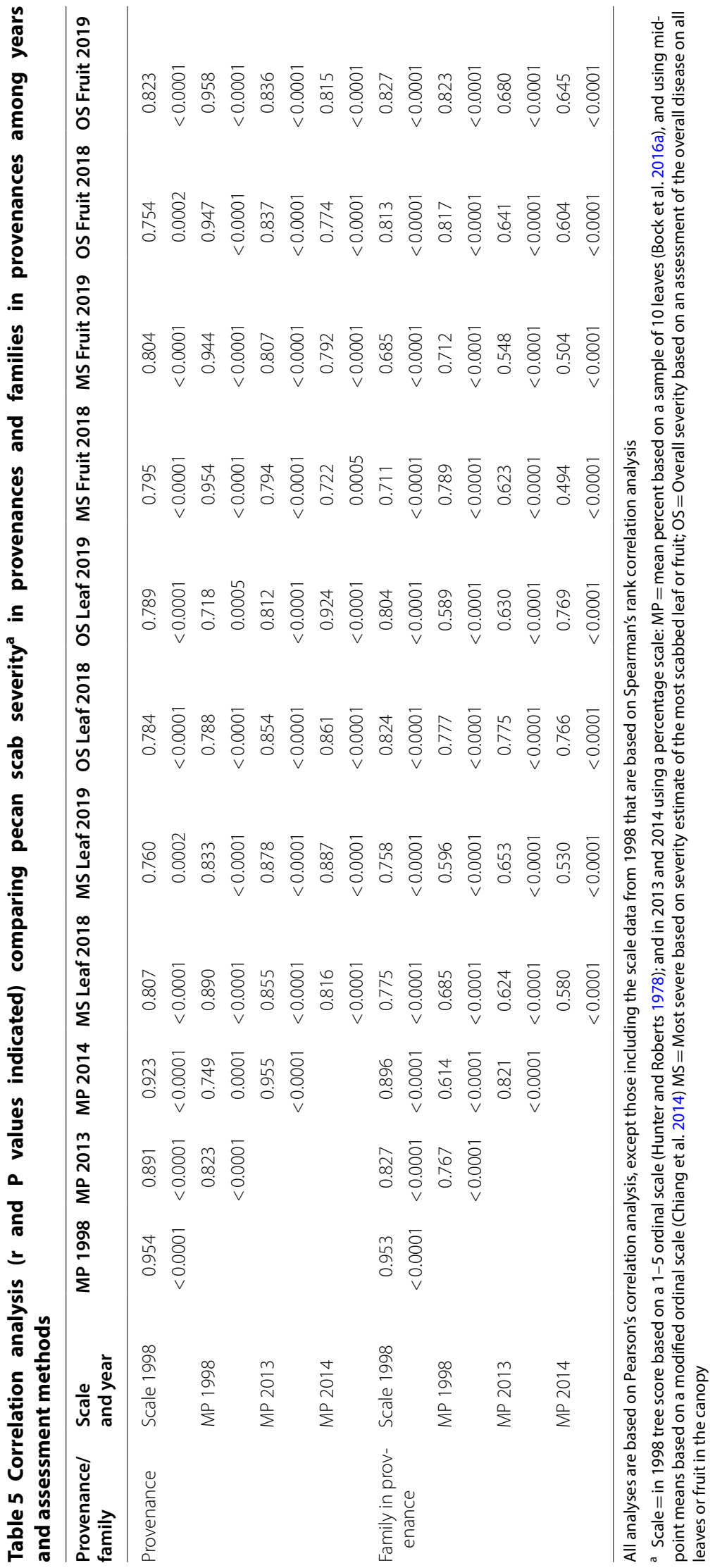


Table 6 Pearson's correlation analysis between the mean maximum or mean overall severity of scab on pecan trees in each of the 19 provenances and various environmental and tree characteristics

\begin{tabular}{|c|c|c|c|c|c|c|c|c|}
\hline & Latitude & Rainfall & Mean temp & Min. temp & Elevation (m) & $\begin{array}{l}\text { Budbreak } \\
\text { (day of year) }\end{array}$ & Leaflet droop $\left({ }^{\circ}\right)$ & Leaflet tilt $\left({ }^{\circ}\right)$ \\
\hline \multirow[t]{2}{*}{ MS Leaf $2018^{a}$} & -0.167 & -0.629 & 0.477 & 0.216 & 0.000 & -0.352 & -0.643 & -0.515 \\
\hline & 0.5 & 0.004 & 0.04 & 0.4 & 1.0 & 0.1 & 0.003 & 0.02 \\
\hline \multirow[t]{2}{*}{ MS Leaf 2019} & -0.245 & -0.689 & 0.503 & 0.309 & 0.062 & -0.410 & -0.732 & -0.608 \\
\hline & 0.3 & 0.001 & 0.03 & 0.2 & 0.8 & 0.08 & 0.0004 & 0.006 \\
\hline \multirow[t]{2}{*}{ OS Leaf 2018} & -0.270 & -0.687 & 0.558 & 0.335 & 0.054 & -0.457 & -0.728 & -0.609 \\
\hline & 0.3 & 0.001 & 0.01 & 0.2 & 0.8 & 0.05 & 0.0004 & 0.006 \\
\hline \multirow[t]{2}{*}{ OS Leaf 2019} & -0.344 & -0.734 & 0.507 & 0.396 & 0.181 & -0.465 & -0.794 & -0.672 \\
\hline & 0.1 & 0.0004 & 0.03 & 0.09 & 0.5 & 0.04 & $<0.0001$ & 0.002 \\
\hline \multirow[t]{2}{*}{ MS Fruit 2018} & -0.347 & -0.584 & 0.418 & 0.327 & 0.256 & -0.353 & -0.582 & -0.441 \\
\hline & 0.1 & 0.009 & 0.07 & 0.2 & 0.3 & 0.1 & 0.009 & 0.06 \\
\hline \multirow[t]{2}{*}{ MS Fruit 2019} & -0.445 & -0.703 & 0.563 & 0.464 & 0.262 & -0.485 & -0.790 & -0.625 \\
\hline & 0.06 & 0.0008 & 0.01 & 0.05 & 0.3 & 0.04 & $<0.0001$ & 0.004 \\
\hline \multirow[t]{2}{*}{ OS Fruit 2018} & -0.187 & -0.527 & 0.373 & 0.190 & 0.087 & -0.274 & -0.499 & -0.393 \\
\hline & 0.4 & 0.02 & 0.1 & 0.4 & 0.7 & 0.3 & 0.03 & 0.10 \\
\hline \multirow[t]{2}{*}{ OS Fruit 2019} & -0.326 & -0.659 & 0.549 & 0.369 & 0.124 & -0.437 & -0.762 & -0.612 \\
\hline & 0.2 & 0.002 & 0.01 & 0.1 & 0.6 & 0.06 & 0.0001 & 0.005 \\
\hline
\end{tabular}

Text in italic indicates significant associations. Matrix plots are presented in Additional file 1: Figure S6

$\mathrm{MS}=$ Most severe based on severity estimate of the most scabbed leaf or fruit; OS=Overall severity based on an assessment of the overall disease on all leaves or fruit in the canopy

a Scab severity was visually estimated based on a modified ordinal scale (Chiang et al. 2014)

-0.81 and to 0.31 to 0.85 ) show the relative strength and relations of the different predictors. Thus, rainfall and leaflet droop angle (both negatively associated with severity) most often contributed to the prediction. Latitude (positively associated), minimum temperature (negatively associated), elevation (negatively associated) and budbreak date (positively associated) had predictive value for only a few of the disease variables. Mean temperature and leaflet tilt angle were not included in predictions of most severe scab or overall scab severity in 2018 or 2019.

\section{Heritability of scab traits}

Heritability of traits associated with scab was relatively low for individual trees and ranged from 0.050 to 0.164 depending on year and whether the estimate was based on the most severe, or overall severity estimate on leaves or fruit (Table 7). However, heritability of traits associated with scab for families was much higher and ranged from 0.308 to 0.685 depending on the year and whether the estimate was based on the most severe, or overall severity estimate on leaves or fruit.

\section{Discussion}

The collection representing 19 unique provenances provides a valuable resource to evaluate severity of leaf and nut scab. The most severely infected leaf or fruit estimate and the overall tree scab estimate obtained from leaves or fruit during this study provided similar and equivalent ratings or rankings. However, they were never the same across years even though the mixed effects ANOVA invariably demonstrated similar rankings of provenances and families, and the correlation analyses confirmed the close associations between these results. Inter-seasonal variation due to differences in weather, timing of epidemic development, and rating methods are expected. The revised rating method adapted from Chiang et al. (2014) offers several advantages including greater resolution in response compared to a five-point scale, but the replication of trees within families and in families within provenances was probably sufficient using the five-point scale (1998 data set, Bock et al. 2016a) to ensure similar differentiation (Bock et al. 2010; Chiang et al. 2016). The rating method and scale used should factor accuracy, reliability, speed and ease of use. Integration of standard area diagrams during the scab rating in real-time increases accuracy (Yadav et al. 2013; Bock et al. 2016b; Del Ponte et al. 2017). Indeed, simulation studies performed using the Hunter-Roberts scale for pecan scab (Hunter and Roberts 1978) demonstrated the advantages and disadvantages of following the described protocol using this disease rating system (Chiang and Bock 2017; Chiang et al., 2017).

Scab severity on trees depended on provenance origin regardless of year of assessment or rating (based on the 
most severely scabbed leaf or fruit, or overall tree severity for leaves or fruit). This was the case in both years, and provenances were reasonably consistent in rankings across years. Based on all assessments in 2018 and 2019 from the overall scab severity rating on leaves or fruit the ranking susceptibility of resistant provenances tended to be similar, although not identical. Thus, the provenances with trees that on average had foliage most resistant were TX-B, TX-G, MX-J, MX-S, TN-L, IL-J, MO-L, MO-V, MS-W, KY-W KS-K and KS-C, and on fruit were fewer but included most of the same provenances TX-B, TN-L, IL-J, MO-L, MO-V, MS-W, KY-W and KS-K. In contrast, provenances with the trees with the most susceptible foliage on average were TX-K, TX-T, TX-V, TX-Z and MX-C, and on fruit were TX-K, TX-T, TX-V, TX-Z, MX-C, MX-I, MX-O and MX-S. Differences between provenances on fruit and foliage may be attributed to the period of time that foliage is susceptible and the inoculum pressure early in the season which may be lower compared to later when the epidemic has developed on fruit. Whereas foliage is only transiently susceptible, fruit is susceptible throughout its lifespan (Gottwald and Bertrand 1983; Gottwald 1985). The provenance susceptibility and rankings were also similar to that reported previously based on various methods assessing scab on foliage alone (Bock et al. 2016a), which was reinforced by the results of the correlation analysis between years and assessments. It is worth noting that in all provenances, trees with a range of scab susceptibility on both foliage and fruit were identified.

All trees in only one family (KS-C-1) were observed to be free of scab on foliage, and all trees in only eight families (KS-C-1, MO-L-4, MS-W-1, MS-W-4, MS-W-5, TN-L-1, TN-L-4, TN-L-6, and TX-B-2) were observed to be free of scab on fruit in both 2018 and 2019. However, this analysis indicates the families within provenances that were consistently resistant to foliar scab include IL-J-1, IL-J-3, KS-C-1, KY-W-2, MO-V-1, TN-L1, TN-L-3, TN-L-4, TX-B-2, and TX-B-5. Conversely, families within provenances that were consistently susceptible to foliar scab include MX-C-1, MX-I-2, MX-O5, TX-K-1, TX-K-4, TX-T-2, TX-T-3, TX-T-5, TX-V-1, TX-V-2, TX-V-3, TX-V-4, TX-V-5, TX-Z-2, TX-Z-4, and TX-Z-5. In general, provenances with families consistently resistant to fruit scab (IL-J-1, KS-C-1, KY-W-5, MO-L-1, MO-L-4, MS-W-1, MS-W-2, MS-W-4, TN-L-1, TN-L-4, TN-L-6, TX-B-2, TX-B-4, TX-B-5, and TX-G-3) shared many with those that exhibited consistent foliar resistance. Similarly, those families within provenances consistently susceptible to fruit scab (MX-C-1, MX-I-2, MX-O-3, MX-S-2, MX-S-5, TX-K-1, TX-K-4, TX-K-5, TX-K-6, TX-T-1, TX-T-2, TX-T-4, TX-T-5, TX-V-1, and $\mathrm{TX}-\mathrm{V}-3$ ) shared several with those that were consistently most susceptible to foliar scab. Nonetheless, the trees within families in different provenances could exhibit a range of susceptibilities to scab, but on average clear tends are apparent. As with the provenances, differences between families within provenances on fruit and foliage could be associated with the prevailing weather. The timing of budbreak, the relative period of time that foliage is susceptible and the inoculum pressure early in the season may affect the severity on a particular genotype. On fruit, the effect may be less prominent as they are susceptible throughout the process of development and maturation, so fruit on all trees will experience common conditions for infection for at least several weeks. Although families within provenances tended to have a range of response to scab, most often they showed ranges of severity trending towards susceptibility, resistance or intermediate responses in both years and for both assessments, as noted previously (Bock et al. 2016a). Strong correlations between severities of scab on families within provenances recorded in 1998, 2013 and 2014, highlights the consistency, repeatability and reliability of the ratings across multiple years. The consistent ratings/rankings suggest that the scab races have been relatively stable and have not changed enough to develop the ability to infect

Table 7 Broad sense heritability by family $\left(\mathrm{H}_{\mathrm{f}}{ }^{2}\right)$ and by tree $\left(\mathrm{H}_{\mathrm{t}}{ }^{2}\right)$ based on the mean maximum or mean overall severity of scab on pecan leaves or fruit of trees in 2018 and 2019 in trees and families in the 19 provenances based on data collected from Byron, GA, USA

\begin{tabular}{|c|c|c|c|c|c|c|c|c|c|}
\hline \multirow[t]{2}{*}{ Assessment } & \multirow[t]{2}{*}{ Tissue } & \multicolumn{4}{|l|}{2018} & \multicolumn{4}{|l|}{2019} \\
\hline & & $\mathrm{H}_{\mathrm{t}}^{2}$ & SE & $\mathrm{H}_{\mathrm{f}}{ }^{2}$ & SE & $\overline{H_{t}{ }^{2}}$ & SE & $\mathrm{H}_{\mathrm{f}}^{2}$ & SE \\
\hline \multirow[t]{2}{*}{ Most severe scab } & Leaves & 0.050 & 0.026 & 0.331 & 0.121 & 0.115 & 0.032 & 0.550 & 0.079 \\
\hline & Fruit & 0.105 & 0.034 & 0.527 & 0.091 & 0.142 & 0.039 & 0.610 & 0.077 \\
\hline \multirow[t]{2}{*}{ Overall scab severity } & Leaves & 0.058 & 0.027 & 0.369 & 0.113 & 0.045 & 0.024 & 0.308 & 0.118 \\
\hline & Fruit & 0.164 & 0.043 & 0.649 & 0.071 & 0.187 & 0.043 & 0.685 & 0.061 \\
\hline
\end{tabular}

SEstandard error 
previously resistant genotypes of pecan over the duration of these assessments.

The provenance collection is genetically diverse and was sourced from a wide range of environments where pecan is endemic (Grauke et al. 1995, 2003; Wood et al. 1998; Rüter et al. 1999; Sagaram et al. 2011). Also, scab prevalence is known to vary substantially across this native range of pecan. Scab occurs primarily in the Southeast from GA to eastern TX, OK and KS, and north to $\mathrm{MO}$ and IL. It is likely that the presence of naturallyoccurring scab isolates has acted as a natural selection driver under which these various populations of pecan have developed. Where scab is prevalent, the pecan populations will be more likely to exhibit resistance. This pattern is reflected in the populations most resistant on foliage and/or fruit originating from TX-B, TX-G, MX-J, MX-S, TN-L, IL-J, MO-L, MO-V, MS-W, KY-W, KS-K, KS-C and MS-W (Fig. 1). These 14 provenances occur in regions where scab also frequently occurs (Bock et al. 2017a). The remaining provenances were from the far west or south of Texas, and from locations in Mexico where rainfall is generally lower and conditions are less conducive to scab. In the areas with lower rainfall, scab resistance would not be a trait under selection. Indeed, based on scab severity, the provenances were most consistently associated with certain environmental variables including negative associations with rainfall and positive associations with minimum temperature, indicating the importance of rainfall for the pathogen development (Gottwald and Bertrand 1982; Sparks et al. 2009). Some biotic variables were also associated with scab severity (particularly negative associations with leaflet tilt and droop angles), as was noted in an earlier report (Bock et al. 2016a). It is unclear whether the leaflet characteristics are directly associated with scab responses, or if they are correlated due to another underlying factor. As noted previously (Bock et al. 2016a), greater droop and tilt angles would tend to minimize water retention, speed leaf drying, which in turn would reduce scab due to the pathogen requirement for surface wetness for infection (Gottwald 1985). However, leaves are rarely supported parallel to the ground and these causal relationships between morphology, humidity and scab responses will require further study. The multiple regression analysis also demonstrated the predictive value of rainfall and leaflet droop angle for scab severity, with budbreak date, elevation and latitude also having some predictive power in some years.

Trees that are native to those provenance origin areas with higher rainfall are more likely to be exposed to severe scab epidemics in the spring and summer. The adaptation to the local scab conditions can result in trees that are resistant to scab, as previously described by
Grauke et al. (1995). The trees from those higher-rainfall areas represent a valuable resource for scab resistance and are being evaluated by the USDA-ARS screening program for scab resistance.

The results from this study are based on scab susceptibility on the 875 (or fewer with fruit assessments) genotypes of pecan in the provenance collection in Georgia. Scab is both pathogenically and genetically diverse (Converse 1960; Conner and Stevenson 2004; Bock et al. 2017b). The mating types are in equilibrium (Young et al. 2018) and a sexual stage has recently been characterized in vitro (Charlton et al. 2020). Scab diversity serving as natural inoculum for the provenance collection in Georgia is unknown. However, the genetic diversity of the pathogen appears to be mostly uniformly distributed over the southeastern region (Bock et al. 2017b), indicating that there is a free flow of genetic material. Therefore, any effector genes associated with particular host genotypes should be readily redistributed through the population, and responsive to selection. The population of $V$. effusa in the central Georgia region has been established for over 100 years in the presence of multiple pecan cultivars grown in the area and that are cultivated throughout the region (very few native trees are grown in GA). The dispersal of the pathogen through wind and water splash allows it to spread locally, and perhaps over moderate distances (Gottwald and Bertrand 1982). Ascospores, if found in the field, may also spread substantial distances. The diversity of tree genotypes within the provenance collection, and the fact that scab is widely able to infect many of the trees suggests that the scab population is highly diverse in regards to pathogenicity, as most pathotypes of scab generally infect only a few genotypes of pecan (Conner and Stevenson 2004). Although some differences could be expected if the provenance collection was exposed to scab populations in an entirely different geographic location or environment, the overall susceptibility of the different genotypes of pecan would most likely be similar. In general, cultivars have equivalent reactions to scab throughout geographical areas in which they are grown in the presence of scab, regardless of region within the USA.

Germplasm from trees in the most resistant provenances and families will be useful to identify the diversity of sources resistant to the scab pathogen, and to understand the mechanisms of resistance. The recent advances and ongoing molecular and genomics work aimed at understanding the pecan genome and developing markers to assist in breeding will aid and accelerate the process of developing scab resistant cultivars (Conner and Wood 2001; Grauke et al. 2003; Beedanagari et al. 2005; Jenkins et al. 2015). To this end, 201 trees with undetectable levels of scab symptoms on leaves and fruit were 
observed in both years. An additional 116 trees did not produce fruit in either year were consistently free of scab symptoms on foliage. Those 201 trees resistant to scab on foliage and fruit in both years originated from 59 families primarily in the provenances IL-J, KS-C, KS-K, KY-W, MO-L, MO-V, MS-W, MX-I, MX-J, TN-L, TX-B and TX-G (mostly higher rainfall provenances). Only a few trees from the provenances MX-O, MX-S, TX-V and $\mathrm{TX}-\mathrm{Z}$ were resistant. The remaining provenances did not have resistant trees in the collection, except for one tree in TX-K with resistance on foliage that did not produce any fruit. It is conceivable the tree 'escaped' disease. The provenance collection includes a significant portion of the genetic diversity in the wild populations of the species (Rüter et al. 1999). Estimates of $94 \%$ of the total diversity are shared between the provenance collection and wild populations. Therefore, field-based assessments of traits represent an excellent resource of characterized diversity available within C. illinoinensis.

The heritability of scab responses ranged between 0.050 and 0.164 for individual trees, and between 0.308 and 0.685 for families depending on year and whether the scab response estimate was based on the most severe, or overall severity estimate on leaves or fruit. In a previous study based on crosses of various parental lines, heritability of scab resistance around $\sim 0.50$ was described (Thompson and Grauke 1994). Also, in a previous report based on scab severity on foliage, Bock et al. (2016a, b) found family heritability ranged between 0.069 to 0.714 , depending on scab rating method and year. Single-tree heritability was 0.026 to 0.194 . These values are in broad alignment with those previous estimates. The values indicate an additive component for scab resistance that would enable progress by selecting parents based on their phenotype.

Additional information on fruit scab severity could further support the relationships between ratings using leaves and fruit. Out of the 875 trees in the provenance collection in Georgia, only 675 trees and 535 trees produced fruit in 2018 and 2019, respectively. Therefore, additional characterization of all trees, including those without fruits in the years of these ratings, over several more years could provide additional insight on the effects due to weather and/or varying scab pressure. Identification of trees that are consistently resistant in multiple years can help us understand mechanisms of scab resistance, and their eventual integration within breeding programs.

\section{Conclusion}

This study describes, for the first-time, scab susceptibility of pecan fruit among the provenances and among families in provenances in the native pecan collection at Byron, Georgia, USA. Severities on fruit, while contrasting in magnitude with foliar ratings, generally resulted in similar rankings among the provenances and among families in provenances regardless of year or rating method. Climatic conditions, particularly rainfall, is likely one of the driving forces behind the prevalence of resistance among trees from certain provenances. Further opportunities to characterize the provenance collection for scab and many other traits of agricultural value can maximize their utilization to address not only pecan scab, but other constraints and challenges to pecan production.

\section{Supplementary information}

Supplementary information accompanies this paper at https://doi. org/10.1186/s43170-020-00020-9.

Additional file 1. Additional Figures S1-S6, Tables S1-S8.

\section{Acknowledgements}

We appreciate the funding support of the USDA-ARS through CRIS project 6042-21220-012-00, CRIS project 3091-21000-042-00, SCRI-NIFA Grant "Coordinated Development of Pecan" (Grant project 2016-51181-25408) and the Noble Research Institute, LLC. This article reports the results of research only. Mention of a trademark or proprietary product is solely for the purpose of providing specific information and does not constitute a guarantee or warranty of the product by the US Department of Agriculture and does not imply its approval to the exclusion of other products that may also be suitable.

\section{Authors' contributions}

CHB, JJR, MJM and LJG conceived and designed the study; CHB and US performed the research; CHB analyzed the data, and CHB, YA and MJM wrote the manuscript; PJC, CAY JJR, LJG, XW and CP contributed to the results, interpretation and provided a critical review of several drafts and the final manuscript. All authors read and approved the final manuscript.

\section{Funding}

Funding support for this study was provided of the USDA-ARS through CRIS project 6042-21220-012-00, CRIS project 3091-21000-042-00, SCRI-NIFA Grant "Coordinated Development of Pecan" (Grant project 2016-51181-25408) and the Noble Research Institute, LLC.

\section{Availability of data and materials}

The datasets used and/or analyzed during the current study are available from the corresponding author on reasonable request.

\section{Ethics approval and consent to participate}

Not applicable.

\section{Consent for publication}

Not applicable.

\section{Competing interests}

The authors declare that they have no competing interests.

\section{Author details}

${ }^{1}$ United States Department of Agriculture (USDA)-Agriculture Research Service (ARS), Southeastern Fruit and Tree Nut Research Lab, 21 Dunbar Road, Byron, GA 31008, USA. ${ }^{2}$ Noble Research Institute, 2510 Sam Noble Parkway, Ardmore, OK 73401, USA. ${ }^{3}$ University of Georgia, 2360 Rainwater Road, Tifton, 
GA 31794, USA. ${ }^{4}$ New Mexico State University, Las Cruces, NM 88003, USA.

${ }^{5}$ USDA-ARS Pecan Breeding and Genetics, Somerville, TX 77845, USA.

Received: 23 July 2020 Accepted: 11 November 2020

Published online: 23 November 2020

\section{References}

Beedanagari SR, Dove SK, Wood BW, Conner PJ. A first linkage map of pecan cultivars based on RAPD and AFLP markers. Theor Appl Genet. 2005;110(6):1127-37.

Blayney D, Gutierrez P. Economic Importance of the Pecan Industry. New Mexico State University, Cooperative Extension Service. Guide Z-501, 4p 2017. https://aces.nmsu.edu/pubs/_z/Z501.pdf.

Bock CH, Gottwald TR, Parker PE, Ferrandino F, Welham S, van den Bosch F, Parnell S. Some consequences of using the Horsfall-Barratt scale for hypothesis testing. Phytopathology. 2010;100:1031-41.

Bock CH, Grauke LJ, Conner P, Burrell SL, Hotchkiss MW, Boykin D, Wood BW. Scab susceptibility of a provenance collection of pecan in three different seasons in the southeastern USA. Plant Dis. 2016a;100:1937-45.

Bock CH, Chiang K-S, Del Ponte EM. Accuracy of plant specimen disease severity estimates: concepts, history, methods, ramifications and challenges for the future. CAB Rev. 2016b;1 1(039):1-13.

Bock CH, Brenneman TB, Wood BW, Stevenson KL. Challenges of managing disease in tall orchard trees-pecan scab, a case study. CAB Rev. 2017a;12(008):1-18.

Bock CH, Hotchkiss MW, Young CA, Charlton ND, Chakradhar M, Stevenson KL, Wood BW. Population genetic structure of Venturia effusa, cause of pecan scab, in the southeastern United States. Phytopathology. 2017b;107:607-19.

Bock CH, Barbedo JGA, Del Ponte EM, Bohnenkamp D, Mahlein A-K. From visual estimates to fully automated sensor-based measurements of plant disease severity: status and challenges for improving accuracy. Phytopathol Res. 2020;2:9. https://doi.org/10.1186/s42483-020-00049-8.

Brenneman TB, Bertrand PF, Mullinix B. Spray advisories for pecan scab: recent developments in Georgia. In: McCraw BE, Dean EH, Wood BW, editors. The pecan industry: current situation and future challenges, Third national pecan workshop proceedings, USDA Agricultural Research Service, Washington D.C., USA 1998-04; pp. 7-14. 1999.

Chaney W, Han Y, Rohla C, Monteros MJ, Grauke LJ. Developing molecular marker resources for pecan. Acta Hort. 2015;1070:127-32.

Charlton ND, Yi M, Bock CH, Zhang M, Young CA. First description of the sexual stage of Venturia effusa, causal agent of pecan scab. Mycologia. 2020;112:711-21.

Chiang K-S, Bock CH. A discussion on disease severity index values. Part II: using the disease severity index for null hypothesis testing. Ann Appl Biol. 2017:171:490-505.

Chiang K-S, Liu S-C, Bock CH, Gottwald TR. What interval characteristics make a good categorical disease assessment scale? Phytopathology. 2014;104:575-85.

Chiang K-S, Bock CH, Lee I-H, El Jarroudi E, Delfosse P. Plant disease severity assessment-how rater bias, assessment method, and experimental design affect hypothesis testing and resource use efficiency. Phytopathology. 2016;106:1451-64.

Chiang K-S, Liu HI, Bock CH. A discussion on disease severity index values. Part l: warning on inherent errors and suggestions to maximize accuracy. Ann Appl Biol. 2017;171:139-54.

Cole JR, Gossard AC. Increased virulence of scab (Cladosporium effusum Wint. Demaree) on Stuart pecan in Mississippi and its presence in Louisiana. Plant Dis Rep. 1956:40:1120.

Conner PJ. Evaluation of response to pecan scab pathogen race using a detached leaflet protocol. HortScience. 2013;48:63-7.

Conner PJ.'Avalon', a new pecan cultivar with high levels of resistance to pecan scab. HortScience. 2018;53(12):1915-8.

Conner PJ, Stevenson KL. Pathogenic variation of Cladosporium caryigenum isolates and corresponding differential resistance in pecan. HortScience. 2004;39:553-7.

Conner PJ, Wood BW. Identification of pecan cultivars and their genetic relatedness as determined by randomly amplified polymorphic DNA analysis. J Am Soc Hort Sci. 2001;126:474-80.
Conner PJ, Worley R. Alternate bearing intensity of pecan cultivars. HortScience. 2000;35:1067-9.

Converse RH. Physiologic specialization in Fusicladium effusum and its evaluation in vitro. Phytopathology. 1960;50:527-31.

de Garcia, M, de Gyves E, de Gyves Z. Nuevo Atlas Porrua de la Republica Mexicana. 6th ed. S.A., Mexico: Editorial Porrua; 1980.

Del Ponte EM, Pethybridge SJ, Bock CH, Michereff SJ, Machado FJ, Spolti P. Standard area diagrams for aiding severity estimation: scientometrics, pathosystems, and methodological trends in the last 25 years. Phytopathology. 2017;98:1543-50.

Demaree JB. Pecan scab with special reference to sources of the early spring infections. J Agric Res. 1924;28(4):321-30.

Demaree JB. Morphology and taxonomy of the Pecan-scab fungus, Cladosporium effusum (Wint.) comb. nov. J Agric Res. 1928;37(3):181-7.

GoffWD, McVay JR, Gazaway WS. Pecan production in the Southeast. Alabama Cooperative Extension System Circular ANR-459. Auburn: University; 1996. p. 222.

Gottwald TR. Influence of temperature, leaf wetness period, leaf age, and spore concentration on infection of pecan leaves by conidia of Cladosporium caryigenum. Phytopathology. 1985;75(2):190-4.

Gottwald TR, Bertrand PF. Patterns of diurnal and seasonal airborne spore concentrations of Fusicladium effusum and its impact on a pecan scab epidemic. Phytopathology. 1982;72:330-5.

Gottwald TR, Bertrand PF. Effect of time of inoculation with Cladosporium caryigenum on pecan scab development and nut quality. Phytopathology. 1983;73:714-8.

Gottwald TR, Bertrand PF. Effects of an abbreviated pecan disease control program on pecan scab disease increase and crop yield. Plant Dis. 1988;72:27-32.

Grauke $\amalg$, Payne JA, Wood BW. North American pecans: a provenance study. Annu Rep N Nut Growers Assoc. 1989;80:124-31.

Grauke $\sqcup$, Thompson TE, Marquard RD. Evaluation of pecan [Carya illinoinensis (Wangenh.) K. Koch] germplasm collections and designation of a core subset. HortScience. 1995;30:950-4.

Grauke L, Iqbal MJ, Reddy AS, Thompson TE. Development of microsatellite DNA markers in pecan. J Am Soc Hort Sci. 2003;128(3):374-80.

Grauke LJ, Mendoza-Herrera M, Miller A, Wood BW. Geographic patterns of genetic variation in native pecans. Tree Gen Genomes. 2011;7(5):917-32.

Holland JB, Uhr DV, Jeffers D, Goodman MM. Inheritance of resistance to southern corn rust in tropical-by-corn-belt maize populations. Theor Appl Gen. 1998;96:232-41.

Huang Y, Xiao L, Zhang R, Wang Z, Zhang Z, Huang C, Huang R, Luan Y, Fan T, Wang J, Shen C, Zhang S, Wang X, Randall JJ, Zheng B, Wu J, Zhang Q, Xia G, Xu C, Chen M, Zhang L, Jiang W, Gao L, Chen Z, Leslie CA, Grauke L, Huang J. The genomes of pecan and Chinese hickory provide insights into Carya evolution and nut nutrition. GigaScience. 2019;8(5):giz036.

Hunter RE. Influence of scab on late season nut drop of pecans. Plant Dis. 1983;67:806-7.

Hunter RE, Roberts DD. A disease grading system for pecan scab. Pecan Q. 1978;12(3):3-6.

Jenkins J, Wilson B, Grimwood J, Schmutz J, Grauke LJ. Towards a reference pecan genome sequence. Acta Hort. 2015;1070:101-8.

NOAA. Climatological data. National Oceanic and Atmospheric Administration. Annual summary (by state). NOAA. 1986.

NOAA. National Oceanic and Atmospheric Administration, National Centers for Environmental Information, Climate Information, Climate Data Online. 2020. https://www.ncdc.noaa.gov/cdo-web/search. Accessed 15 May 2020.

Rüter B, Hamrick JL, Wood BW. Genetic diversity within provenance and cultivar germplasm collections versus natural populations of pecan (Carya illinoinensis). J Hered. 1999;90:521-8.

Sagaram M, Lombardini L, Grauke LJ. Variation in anatomical characteristics in leaves of pecan seedstocks from Mexico and the United States. J Am Soc Hort Sci. 2011;136:103-8.

Sanderlin RS. Effect of nut scab on pecan yield and quality components. Pages 45-49. In: Sustaining pecan productivity into the 21st century: Second national pecan workshop proceedings, Wagoner, Oklahoma, July 23-26, 1994. U.S. Dept. Agric., Agriculture Research Service, 1995-3, 195 pp. 1995.

Saxton AM. A macro for converting mean separation output to letter groupings in Proc Mixed. In Proc. 23rd SAS Users Group Intl., SAS Institute, Cary, 
NC, pp 1243-1246. Nashville, TN, March 22-25, 1998. http://www2.sas com/proceedings/sugi23/Stats/p230.pdf.

Sneath PH, Sokal RR. Numerical taxonomy: the principles and practice of numerical classification. 1st ed. San Francisco: W. H. Freeman; 1973.

Sokal RR, Michener CD. A statistical method for evaluating systematic relationships. Kansas: University of Kansas; 1958. p. 30.

Sparks D. Pecan cultivars: the orchards foundation. Watkinsville: Pecan Production Innovations; 1992.

Sparks D, Yates IE, Bertrand PF, Brenneman TB. The relative importance of elevation and rainy days on the incidence of scab damage of pecan nuts in the southeastern USA. J Hort Sci Biotechnol. 2009:84:137-42.

Standish JR, Brenneman TB, Bock CH, Stevenson KL. Fungicide resistance in Venturia effusa, cause of pecan scab: current status and practical implications. Phytopathology. 2020. (Accepted)

Stevenson KL, Bertrand PF. Within-season dynamics of yield loss due to pecan scab fruit infections. Phytopathology. 2001;91:S85.

Stone DE. Juglandaceae. In: Kubitzki K et al., editors. 1990+. The families and genera of vascular plants. 2 +vols. Berlin etc. Vol. 2, pp. 348-359. 1993. http://www.efloras.org/florataxon.aspx?flora_id=18taxon_id=21000 0185.

Thompson TE, Conner PJ. Pecan (Chapter 20). In: Badenes ML, Byrne DH, editors. Fruit breeding, Handbook of plant breeding 8, 771. USDAARS/University of Nebraska, Lincoln Faculty. 1322; 2012. https://doi. org/10.1007/978-1-4419-0763-9_20. https://digitalcommons.unl.edu/ usdaarsfacpub/1322.

Thompson TE, Grauke LJ. Genetic resistance to scab disease in pecan. HortScience. 1994:29:1078-80.

Thompson TE, Reid W, Grauke LJ. 'Lakota' pecan. HortScience. 2008;43:250-1.

USDA. 2020. United States Department of Agriculture, National Agricultural

Statistics Service Information. https://www.nass.usda.gov/Statistics_by_ Subject/index.php?sector=CROPS. Accessed 27 May 2020.
Wells L. Pecan planting trends in Georgia. HortTechnology. 2014;24:475-9.

Wells L. Pecan: America's native nut tree. Tuscaloosa: The University of Alabama Press; 2017.

Wells L, Brenneman T, Brock J, Culpepper AS, Hudson W, Mitchem W. 2018 Commercial pecan spray guide. University of Georgia Extension. Bulletin 841. 2018. http://www.caes.uga.edu/commodities/fruits/pecan/docum ents/2018-Pecan-Spray-Guide.pdf.

Wood BW, Payne JA, Grauke LJ. The rise of the U.S. pecan industry. HortScience. 1990;25:594, 721-722.

Wood BW, Grauke LJ, Payne JA. Provenance variation in pecan. J Am Soc HortSci. 1998;123:1023-8.

Wood BW, Conner PJ, Worley RE. Relationship of alternate bearing intensity in pecan to fruit and canopy characteristics. HortScience. 2003;38:361-6.

Wright JW. Provenance testing. In: Introduction to Forest Genetics. New York: Academic Press; 1976. p. 253-65.

Yadav NVS, de Vos SM, Bock CH, Wood BW. Development and validation of standard area diagrams to aid assessment of pecan scab symptoms on fruit. Plant Pathol. 2013;62:325-35. https://doi.org/10.111 1/j.1365-3059.2012.02641.x.

Young CA, Bock CH, Charlton ND, Chakradhar M, Krom N, Bowen JK, Templeton M, Plummer KM, Wood BW. Evidence for sexual reproduction: identification, frequency and spatial distribution of Venturia effusa (pecan scab) mating type idiomorphs. Phytopathology. 2018;108:837-46.

\section{Publisher's Note}

Springer Nature remains neutral with regard to jurisdictional claims in published maps and institutional affiliations.
Ready to submit your research? Choose BMC and benefit from:

- fast, convenient online submission

- thorough peer review by experienced researchers in your field

- rapid publication on acceptance

- support for research data, including large and complex data types

- gold Open Access which fosters wider collaboration and increased citations

- maximum visibility for your research: over $100 \mathrm{M}$ website views per year

At $\mathrm{BMC}$, research is always in progress.

Learn more biomedcentral.com/submissions 